\title{
A Exposição Universal de Chicago (1893): reflexões sobre o lugar dos Estados Unidos no mundo na virada do século XIX para o XX
}

\author{
Gabriela Xabay Gimenes ${ }^{1}$
}

\begin{abstract}
Resumo: A Exposição Universal de 1893 foi um evento internacional de grandes proporções que impactou o imaginário norte-americano no final do século XIX. Sediada na cidade de Chicago, a grande metrópole do Oeste, a Exposição celebrava o quadringentésimo ano da chegada de Cristóvão Colombo ao Novo Mundo. Um dos principais objetivos dos organizadores do evento, no entanto, era apresentar o recente êxito industrial e econômico que os Estados Unidos obtiveram nas últimas décadas do século. Milhões de pessoas visitaram Chicago para assistir as apresentações e ver as atrações, que aconteceram entre maio e outubro daquele ano. Este artigo pretende discutir elementos da Exposição Universal de 1893 e o controle da produção e circulação de imagens, especialmente as fotografias, sobre o evento.
\end{abstract}

Palavras-chave: Exposições universais; Estados Unidos; representações visuais.

\section{Chicago World's Fair (1893): reflections on the place of the United States at the turn of the twentieth century}

\begin{abstract}
The 1893 World's Fair was a major international event, which profoundly affected the American imaginary toward the end of the nineteenth century. Held in Chicago, the great western metropolis, the exposition was meant to celebrate the fourhundredth anniversary of Christopher Columbus' arrival in the New World. One of the main goals of the organizers, however, was to promote the industrial and economic success that the United States achieved in the last decades of the century. Millions of people visited Chicago to attend the exhibitions and presentations that took place from May to October of that year. This article discusses aspects of the 1893 World's Fair, and it examines the control over production and circulation of images, notably photographs, on the event.
\end{abstract}

Keyword: World's Fair; United States; visual representations.

Artigo recebido em: 30/06/2016

Artigo aprovado para publicação em: 07/01/2017

\footnotetext{
${ }^{1}$ Mestra pelo Programa de Pós-Graduação em História Social da Universidade de São Paulo. Bolsista da Fundação de Amparo à Pesquisa de São Paulo. E-mail: gabrielaxabay@gmail.com
}

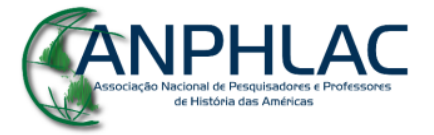

Revista Eletrônica da ANPHLAC, ISSN 1679-1061, №. 22, p. 147-181, Jan./Jun., 2017.

http://revista.anphlac.org.br 
As atenções do mundo ocidental se voltaram a Chicago no final do século XIX. Superando as desconfianças quanto à viabilidade do projeto, a cidade abrigou a Exposição Universal de 1893. O evento de descomunal proporção foi talvez o ponto de inflexão decisivo na trajetória de Chicago, que, à época, já assumia feições de uma metrópole alucinante. Foi, no entanto, a partir da Exposição que a cidade ganhou respeito e prestígio internacional. Deixou de ser lembrada como uma pequena localidade do Oeste dos Estados Unidos, para ser evocada como um dos palcos da modernidade. Essa mudança de percepção se deveu tanto a constatações reais quanto a construções ficcionais, que muitas vezes se entrelaçavam em uma narrativa coesa e sem conflitos.

Chicago, de fato, era uma cidade extraordinária, logrando em pouco mais de meio século se tornar o segundo maior centro populacional do país. ${ }^{2}$ Some-se a esse roteiro de um incêndio em 1871, que destruiu o centro comercial da cidade e exigiu sua reconstrução, e temos assim o esboço de uma epopeia. Essa versão da história da cidade deixou os rascunhos para ser propagandeada durante a Exposição Universal de 1893. E apesar de sua protagonista ser Chicago, a narrativa evocava uma ideia de Estados Unidos modernos, como se o país fosse o exemplo de sucesso distante das terras da Europa. E de qual maneira seria mais oportuno começar essa história, senão com o Velho Mundo?

A Exposição de Chicago foi antes de tudo uma celebração. O evento tinha como pretexto a comemoração do quadringentésimo ano da chegada de Cristóvão Colombo às Américas — ou melhor, à ilha de Guanaani, atual San Salvador. Segundo Edmundo O’Gorman (2002), a ideia de América e de Descobrimento foi forjada na Europa. Aos poucos, esse constructo europeu foi sendo assimilado pelos habitantes das colônias. Ao final do século XVIII, o mito do Descobrimento foi incorporado à narrativa histórica de diversos países das Américas com a intenção de buscar uma unidade nacional forjada na origem destas nações. Por vezes ignorado pela historiografia, foi o aniversário do Descobrimento que deu origem e nutriu a opinião pública sobre a importância de uma exposição.

\footnotetext{
${ }^{2}$ Chicago foi oficialmente fundada em 1833. Em sua origem, a cidade era um pequeno vilarejo que servia de entreposto para as viagens ao Oeste. No final da década de 1890, a cidade ultrapassou a Filadélfia como o segundo maior centro urbano dos Estados Unidos com 1,1 milhão de habitantes, perdendo apenas para Nova York, que concentrava 1,5 milhão de residentes (UNITED STATES CENSUS BUREAU, 1890).
}

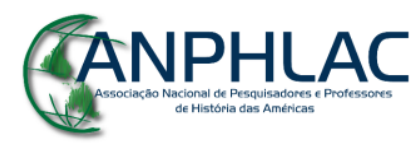


Segundo o historiador Thomas Schlereth, Cristóvão Colombo só foi "descoberto" nos Estados Unidos durante o período da Independência (1775-1783), quando os colonos da América procuraram se dissociar politicamente dos britânicos. A figura de Colombo acabou sendo elevada por poetas, intelectuais e artistas a uma posição de ancestral, deixando de ser um italiano para se tornar o "primeiro norteamericano" (SCHLERETH, 1992, p. 937-939). No início do século XIX, a figura histórica de Colombo transformou-se em Columbia, uma alegoria feminina que personificava a nação norte-americana. Nos anos da expansão para o Pacífico, tanto Cristóvão Colombo, figura histórica, quanto Columbia foram enaltecidos. Seus feitos nas viagens transatlânticas inspiravam os avanços para o Oeste, através de expedições perigosas, em meio a uma natureza muitas vezes inóspita, além de justificar as guerras contra os povos indígenas. (SCHLERETH, 1992, p. 946)

Na década de 1880, a mitologia sobre Colombo recebeu novo impulso com a intensa imigração de italianos para cidades como Nova York e Chicago, que elegeram o navegador genovês como símbolo de sua nova realidade em terras americanas. Outubro de 1892, efeméride do Descobrimento, foi se constituindo como uma data importante no calendário daquele país. A sociedade civil pressionou o governo a instituir naquele ano o Columbus Day, que deu origem a uma série de manifestações de patriotismo nos Estados Unidos. A Exposição de Chicago fez parte das comemorações, apesar de ter sido inaugurada apenas em maio de 1893, devido a atrasos nos canteiros de obras.

Durante a Exposição, o mito do Descobrimento foi largamente relembrado. Para financiar parte do evento, o governo norte-americano decidiu emitir a primeira moeda comemorativa do país, além de uma série de selos postais que tinham Colombo como temática.
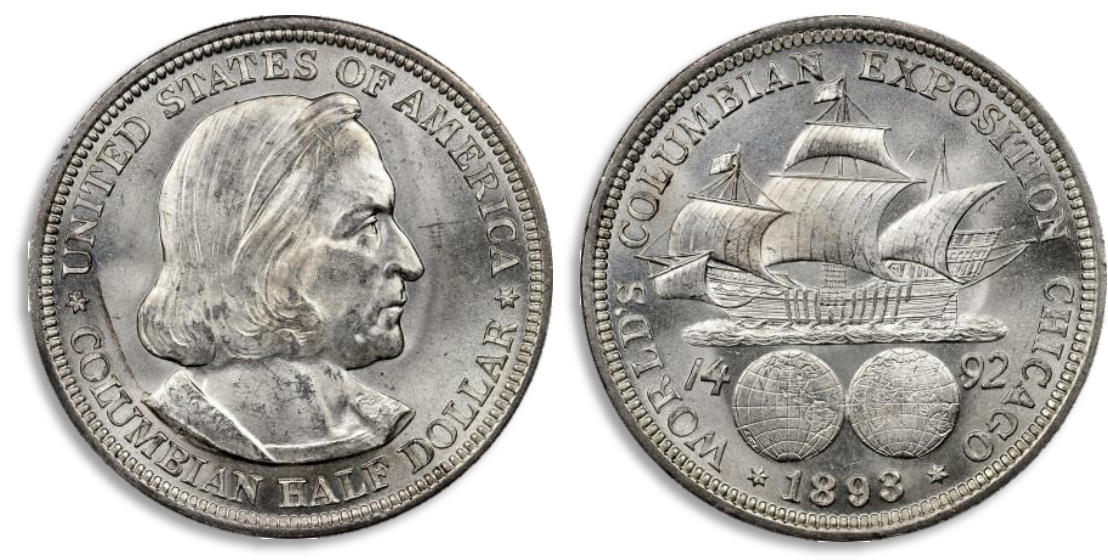

\section{CANPHLAC}

Revista Eletrônica da ANPHLAC, ISSN 1679-1061, №. 22, p. 147-181, Jan./Jun., 2017.

http://revista.anphlac.org.br 
Imagem 1 - Moeda comemorativa da Exposição de Chicago emitida em 1893 pelo governo norteamericano (acervo pessoal). No anverso da moeda, encontra-se a efígie de Colombo - que nunca foi retratado por pintores enquanto estava vivo. No reverso, aparece uma representação da nau de Santa Maria no mar, com as velas içadas. Logo abaixo, lê-se "1492", ano do Descobrimento. A data é dividida por duas esferas: as representações cartográficas de dois hemisférios, um deles englobando todo o continente americano, o Novo Mundo, e o outro, a Europa, a Ásia e a África.

$\mathrm{Na}$ Exposição, os organizadores também ergueram uma réplica em tamanho real do Mosteiro de La Rabida, onde Colombo teria se preparado antes de partir para sua viagem, e construíram reproduções das embarcações Niña, Pinta e Santa Maria, que aportaram nas ilhas da América Central em 1492.

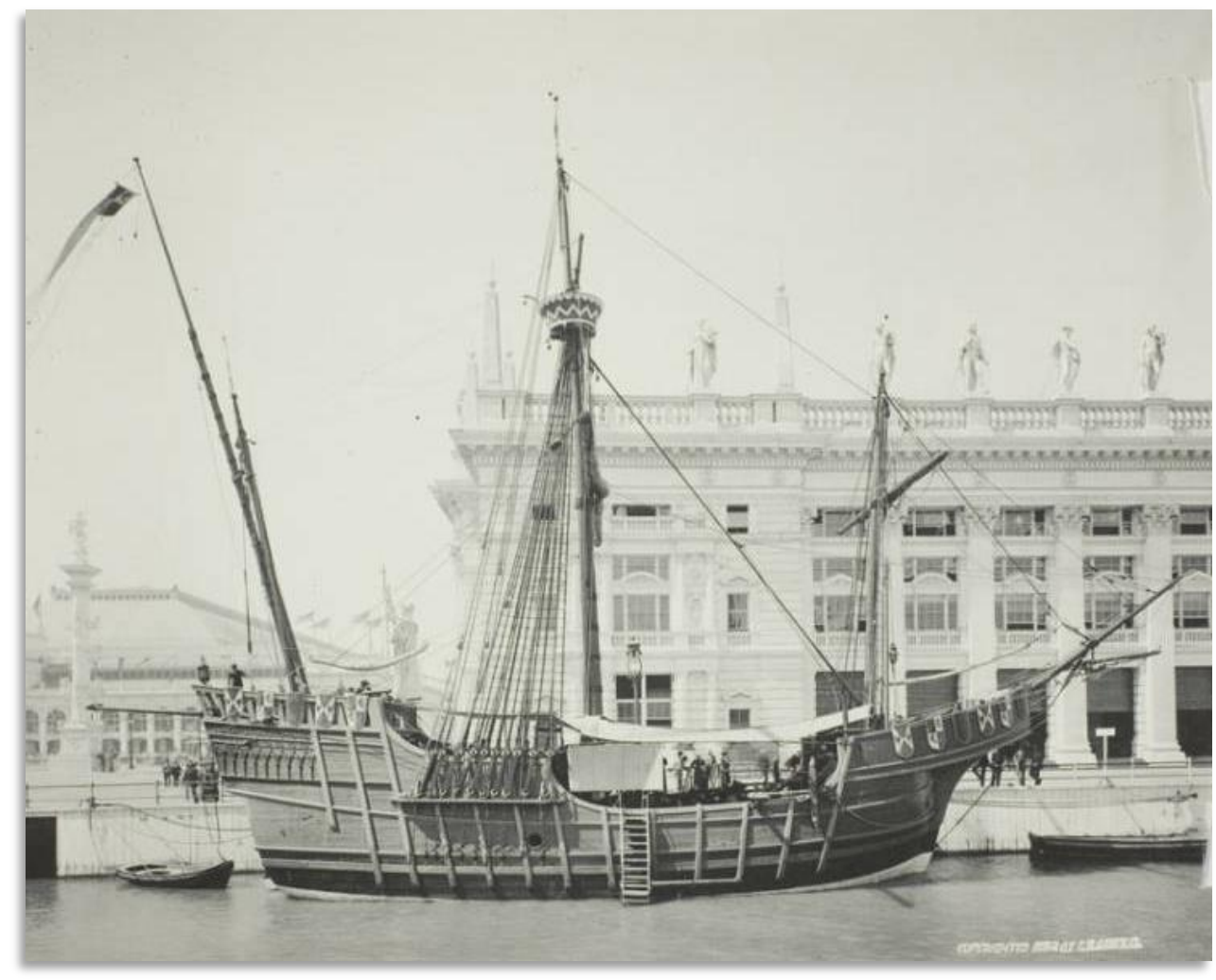

Imagem 2 - Réplica da nau de Santa Maria. As três embarcações foram construídas e dadas de presente pelo governo da Espanha e depois guinchadas por navios da U. S. Navy até a fronteira com o Canadá. De lá, fizeram uma peregrinação pela Costa Leste dos Estados Unidos até chegar às margens do lago Michigan, no Jackson Park, onde ficaram atracadas até o final da Exposição. Fotografia de C. D. Arnold em platinotipia (Coleção World's Columbian Exposition Photographs do Art Institute of Chicago).

A rememoração enfática da chegada do navegante ao continente americano não foi uma escolha ao acaso. O passado de Colombo - que teria refutado racionalmente a superstição de que a Terra era plana - era o primeiro capítulo de uma história de glórias norte-americanas. No final do século XIX, Colombo foi tratado como um herói

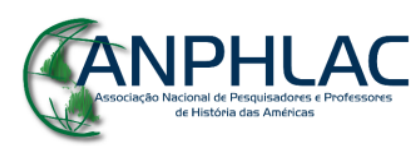

Revista Eletrônica da ANPHLAC, ISSN 1679-1061, №. 22, p. 147-181, Jan./Jun., 2017. http://revista.anphlac.org.br 
racionalista no embate entre a ciência e a religião, pela sua suposta defesa da esfericidade da Terra. Mas, segundo Schlereth, a tese de que o planeta era esférico já havia se popularizado entre a maioria dos letrados medievais (SCHLERETH, 1992, p. 953-955). Ao misturar exibições históricas com mostras tecnológicas, científicas e de belas artes, os organizadores criaram uma narrativa teleológica, em um percurso intencional que parecia ter como destino final os Estados Unidos moderno, a mais nova potência fora do Velho Mundo.

\section{Do Palácio de Cristal (1851) à noite iluminada de Chicago (1893)}

Chicago não foi a primeira cidade a abrigar uma exposição dessa natureza. Esses eventos ocorreram com certa frequência a partir da segunda metade do século XIX. A primeira grande exposição moderna aconteceu em Londres em 1851. A Exposição do Crystal Palace, como o evento ficou conhecido, foi responsável por introduzir o espírito do progresso ao universo das exposições, trazendo máquinas inovadoras e realizações científicas. (PESAVENTO, 1997, 72-84) Imaginários futuristas rondaram as exposições universais que se tornaram espaços identificados com os avanços tecnológicos de seu período. Invenções como o telégrafo, a ceifeira mecânica, a máquina de escrever, o fonógrafo, o telefone e o elevador foram apresentadas e difundidas por meio desses eventos.

Em Chicago, foram as lâmpadas elétricas e os geradores de corrente alternada que ganharam destaque. A união dos dois dispositivos permitiu que algumas exibições ficassem abertas durante a noite, algo inédito nesses eventos.

\section{GANPHLAC}




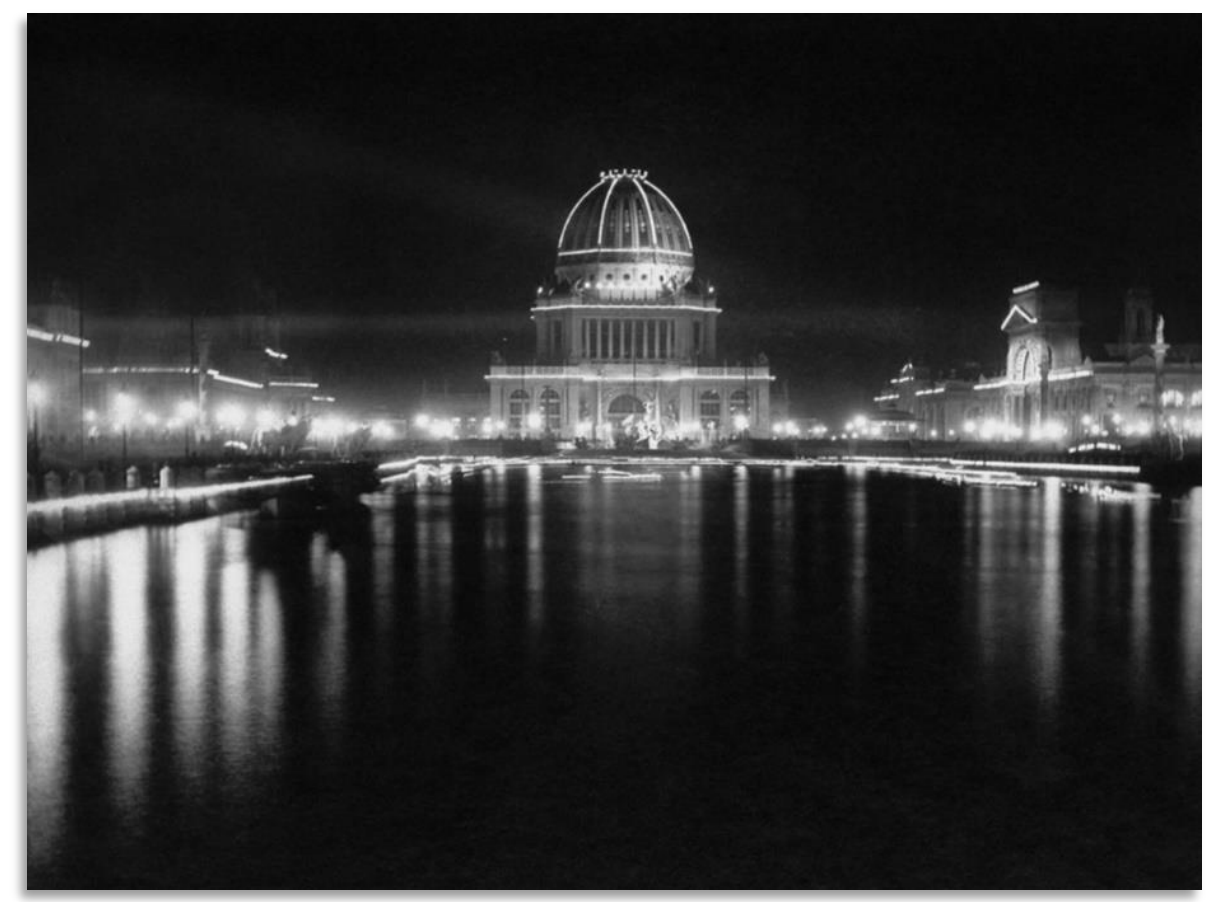

Imagem 3 - O prédio da Court of Honor iluminado à noite. A Exposição de Chicago foi a primeira a utilizar a energia elétrica em larga escala. As luzes dos prédios e dos postes refletiam no espelho d'água, aumentando ainda mais o impacto visual. Fotografia de C. D. Arnold em platinotipia (acervo do Chicago History Museum).

A contratação dos serviços de iluminação da Exposição foi alvo de intensa disputa entre empresários norte-americanos e cientistas. Durante a década de 1880, Thomas Edison se opôs vigorosamente ao modelo de corrente alternada do recémnaturalizado norte-americano Nikola Tesla, que permitia que a eletricidade fosse distribuída a distâncias mais afastadas de seu ponto gerador. A invenção colocava em risco as diversas patentes de dispositivos inventados por Edison, que funcionavam com corrente contínua. Tesla saiu vitorioso da disputa, afastando as desconfianças que pairavam sobre o seu nome - muitas delas criadas pelo seu adversário (CHENEY; UTH, 1999, p. 13-34). A Westinghouse Electric, que contratou Tesla e detinha a patente do gerador de corrente alternada, ganhou a licitação para iluminação da Exposição de 1893, um dos episódios que foram decisivos para a adoção do modelo de produção de energia elétrica que utilizamos até hoje. (JONNES, 2003, p. 247-266)

\section{GANPHLAC}

Revista Eletrônica da ANPHLAC, ISSN 1679-1061, №. 22, p. 147-181, Jan./Jun., 2017.

http://revista.anphlac.org.br 


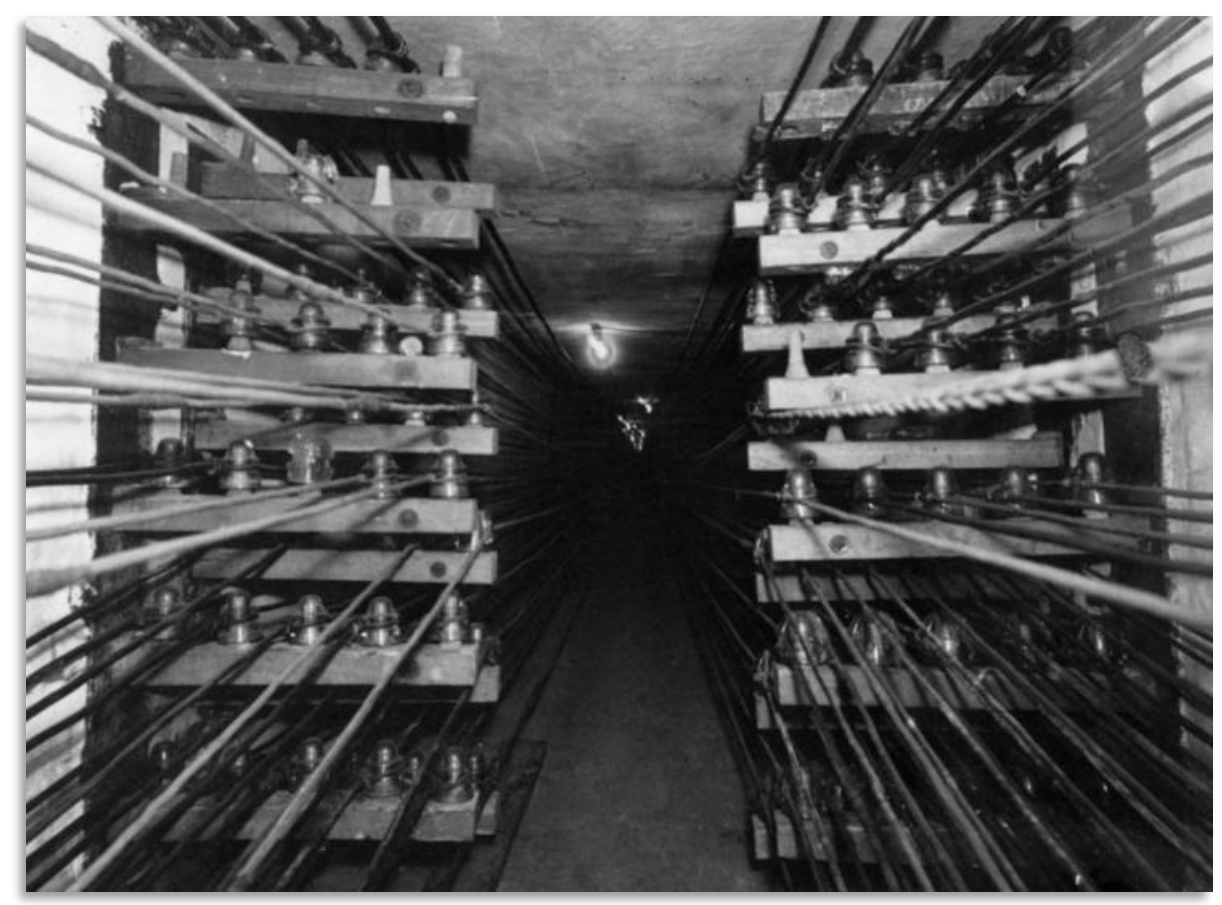

Imagem 4 - Fotografia das instalações elétricas subterrâneas da Exposição de Chicago. A opção inusitada de fotografar a rede elétrica se justifica pelo emprego da nova tecnologia e como uma forma de demonstrar o potencial industrial dos Estados Unidos. Fotografia de C. D. Arnold em platinotipia (coleção World's Columbian Exposition Photographs do Art Institute of Chicago).

As exposições universais não eram apenas vitrines para invenções. Esses eventos, especialmente os mais próximos à virada do século XIX, tinham por objetivo representar o mundo em sua totalidade — ou o que eles concebiam como mundo - , em um espaço delimitado e controlado. Segundo a historiadora Heloisa Barbuy, as exposições mantiveram esse caráter industrial, visionário e totalizante até a Primeira Guerra Mundial (1914-1918), quando perderam sua pretensão universal para se especializar em alguma temática. (BARBUY, 1999, p. 38-39)

Não é coincidência que as exposições universais tenham surgido justamente na segunda metade do século XIX, junto com a Segunda Revolução Industrial. Para Francisco Foot Hardman, as exibições materializavam o mundo burguês, seu culto às máquinas industriais e ao universo das mercadorias. Funcionavam como um verdadeiro espetáculo do capitalismo, no qual os traços mais positivos do processo de industrialização eram apresentados, enquanto os aspectos desfavoráveis, silenciados. (HARDMAN, 2005, p. 62-81)

As feiras mundiais tinham claros objetivos pedagógicos, já que elas eram destinadas a um amplo público, inclusive operários de fábricas — em um período

\section{GANPHLAC}

Revista Eletrônica da ANPHLAC, ISSN 1679-1061, №. 22, p. 147-181, Jan./Jun., 2017.

http://revista.anphlac.org.br 
marcado pelo aprofundamento das tensões nas relações de trabalho. (PESAVENTO, 1997, p. 43-48; DIRKS et al., 1994, p. 124) As mostras e exibições eram montadas com o objetivo de conquistar corações e mentes dos visitantes, causando estupor e fascínio. Até a criação e popularização do rádio nas primeiras décadas do século $\mathrm{XX}$, a circulação de ideias entre as elites e a população acontecia de maneira restrita, principalmente através da educação básica, jornais e livros. As exibições facilitavam o trânsito de pensamentos científicos, culturais e políticos entre o meio acadêmico e as camadas dirigentes, como também os disseminavam para a população em geral. (EVERDELL, 2000, p. 24-25) Diversas concepções sobre raça, cultura, progresso e modernidade foram difundidas e popularizadas através desses eventos. Foi precisamente essa característica de propagação de valores e ideias que tornou a exposição universal uma das principais armas culturais do capitalismo no século XIX, além de ser um espaço privilegiado para transações econômicas.

Para criar uma ilusão de um microcosmo, os organizadores das feiras contavam com a participação de países estrangeiros interessados em exibir os símbolos de seu progresso e suas supostas vocações ao mundo. Com pavilhões, stands de produtos, mostras culturais, os expositores apresentavam e vendiam seus produtos, bem como negociavam a imagem de seu país. Tomemos como exemplo a participação brasileira na Exposição de 1893.

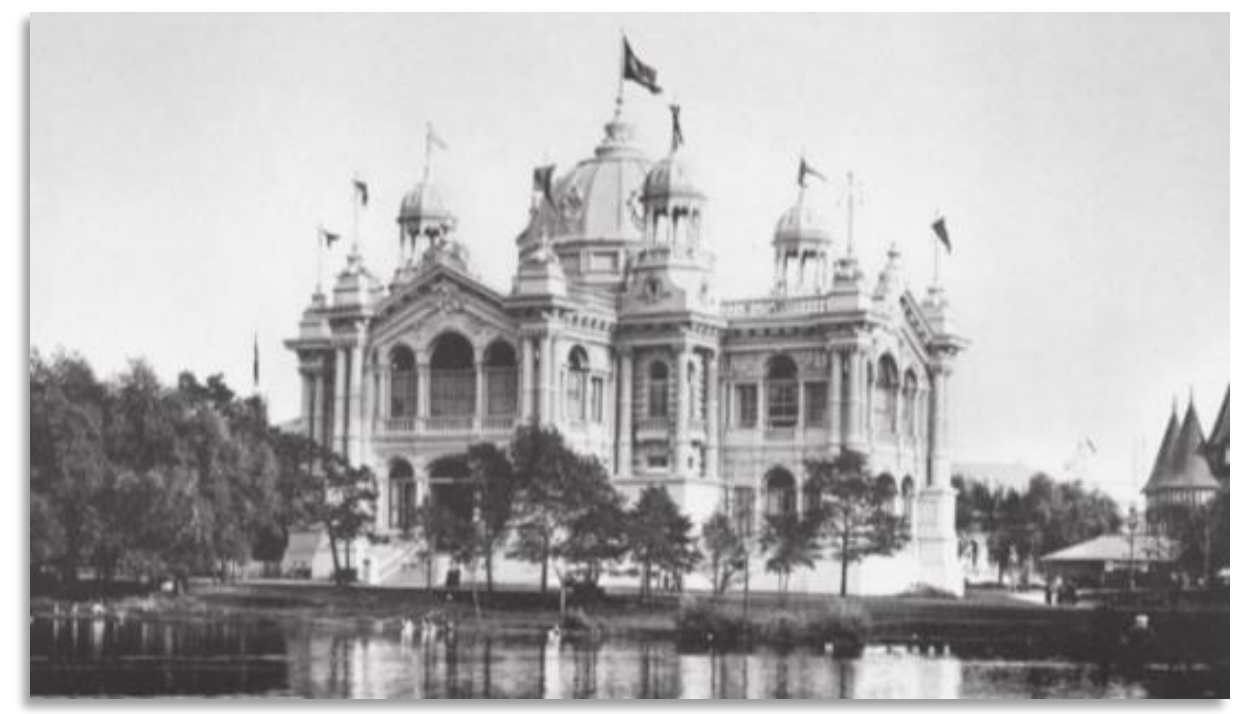

Imagem 5 - Prédio brasileiro na Exposição de Chicago, construído em estilo eclético pelo engenheiro Francisco de Souza Aguiar. Fotografia de C. D. Arnold em platinotipia, reproduzida no álbum Official Views of the World's Columbian Exposition, plate 74.

\section{CANPHLAC}

Revista Eletrônica da ANPHLAC, ISSN 1679-1061, №. 22, p. 147-181, Jan./Jun., 2017. 
Composta por cientistas, intelectuais, militares e empresários, a delegação do país não mediu esforços para comercializar o principal produto da nação, o café. $\mathrm{O}$ Brasil - ou melhor, um grupo de fazendeiros do Rio de Janeiro e São Paulo — optou por erguer um prédio próprio, onde mudas da planta eram expostas e a bebida era servida ao público norte-americano. Adolpho Augusto Pinto, engenheiro urbanista paulista que trabalhou informalmente como correspondente de O Estado de São Paulo, fez um breve relato de viagem, no qual descreveu os esforços da delegação para buscar novos compradores para o produto. Os representantes brasileiros, contudo, sabiam que havia algo menos tangível na mesa de negociações: em Chicago, eles deveriam vender uma nova imagem de Brasil, agora republicano. Não foram apenas sacas de café que chegaram aos Estados Unidos. Os comissários do país se esforçaram em reunir um vasto material literário e algumas pinturas, entre elas, a famosa tela histórica de Pedro Américo, "Independência ou Morte" (1888), e "Martírio de Tiradentes" (1893), de Francisco Aurélio de Figueiredo e Melo. "Independência ou Morte" mede impressionantes $4,15 \mathrm{~m}$ de altura por $7,60 \mathrm{~m}$ de largura; o quadro foi chumbado na parede do Salão Nobre do Museu do Ipiranga dois anos depois, em 1895. "Martírio de Tiradentes" foi concluído no ano da Exposição Universal e reflete os interesses das elites republicanas em buscarem um novo herói nacional para o Brasil. O compositor de ópera Carlos Gomes também foi convidado a ir para Chicago, onde realizou algumas apresentações. Esses breves apontamentos de movimentações no campo cultural dão indícios da mensagem que a elite brasileira desejava comunicar ao resto do mundo, qual seja, a de que o Brasil também pertencia ao mundo "civilizado". 3

Se países estrangeiros participantes sofriam pressões para montar exibições interessantes e memoráveis, a responsabilidade sobre os ombros do país anfitrião era ainda maior. Sediar um evento como esse, que normalmente assumia dimensões extraordinárias, carregava uma série de valores simbólicos. Ainda que seja um exercício anacrônico e limitado, é possível traçar um paralelo entre o peso de abrigar essas exposições com as responsabilidades atuais de trazer um evento de expressão

\footnotetext{
${ }^{3}$ Guatemala, Costa Rica, Venezuela, Colômbia e Haiti foram os outros países latino-americanos que optaram por erguer prédios que remetiam à arquitetura típica de suas casas e palacetes. Esses exibidores estavam interessados em destacar e montar grandes mostras de seus principais produtos, como o café, o cacau, o açúcar e madeiras locais, em uma atitude mais assertiva para conquistar os mercados norteamericanos.
}

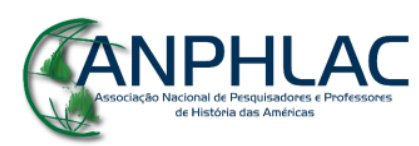

Revista Eletrônica da ANPHLAC, ISSN 1679-1061, №. 22, p. 147-181, Jan./Jun., 2017. http://revista.anphlac.org.br 
internacional, como as Olimpíadas — recriadas em 1896. O fracasso de uma exposição poderia caracterizar negativamente o país sede, enquanto um bom resultado traria glórias e elevaria a imagem da nação no exterior. Se levarmos em conta que o mundo estava cindido entre nacionalismos no final do século XIX, não seria exagero supor que as projeções dos países nesse tipo de evento se tornaram cada vez mais importantes.

Para os Estados Unidos, isso não foi diferente. A Exposição Universal de 1893 foi a segunda dessa natureza sediada nos Estados Unidos; a primeira aconteceu na Filadélfia em 1876, em razão do centenário da Declaração de Independência. Entretanto, Chicago foi o primeiro evento em que o país pode desfrutar de sua nova posição geopolítica alcançada pelo desenvolvimento econômico das décadas de 1870 e 1880 - período que ficou caracterizado pela historiografia norte-americana como Gilded Age.

Antes mesmo do início da Guerra Civil (1861-1865), os Estados Unidos já vivenciavam um crescimento industrial, particularmente no Norte. O processo da Guerra, e posteriormente o da Reconstrução (1865-1877), acelerou a construção de estradas de ferro, que era um dos principais setores industriais do país, e o desenvolvimento dos meios de comunicação, especialmente o telégrafo. (TRACHTENBERG, 1997, p. 4) Os territórios do Oeste foram os maiores beneficiários dessa expansão industrial, fazendo com que o interior dos Estados Unidos, especialmente a região dos Grandes Lagos, onde Chicago está localizada, se tornasse um novo centro econômico para o país. (CASHMAN, 1993, p. 8)

A Exposição foi um dos acontecimentos de maior importância no final do século XIX, sendo certamente um dos mais noticiados pela imprensa do país. (MOTT, 1941, p. 577-578) Estima-se que 25 milhões de ingressos para as exibições foram vendidos, um número expressivo se considerarmos que a população norte-americana era composta por aproximadamente 63 milhões de pessoas. (UNITED STATES CENSUS BUREAU, 1990) Ao todo, 53 países participaram oficialmente da Exposição, distribuindo-se entre pavilhões e prédios próprios, construídos em uma área de $2,5 \mathrm{~km}^{2}$, sendo cerca de 100 construções erguidas especificamente para o evento. (HANDY, 1893, p. 105) Além dos países que participavam voluntariamente, a Exposição de Chicago contou também com atrações promovidas por indivíduos e companhias. As exibições sobre a China, por exemplo, não foram autorizadas pelo governo do país, mas estavam presentes em

\section{GANPHLAC}


Chicago por conta desses agenciadores. Na organização da Exposição, havia uma complexa rede de empresários, cientistas de renomadas instituições norte-americanas, líderes políticos e órgãos governamentais que uniram esforços para financiar e organizar o evento.

\section{Conflitos e dissensões na organização de uma exposição nacional}

Desde que a ideia de uma exposição universal começou a ser ventilada na imprensa norte-americana, políticos e empresários do país se digladiaram para ter alguma participação, influência ou lucro através do evento. O capital gerado pela Exposição da Filadélfia, 17 anos antes, certamente alimentou as esperanças e os interesses de diversos grupos — entre eles, empresários, negociantes e financistas que acreditavam que a Exposição de 1893 traria o mesmo sucesso econômico. (RYDELL, 1984, p. 42) Na década de 1880, cidades como Saint Louis, Washington, Chicago e Nova York manifestaram interesse em se tornar a sede da exposição que aconteceria em 1892. Quem saísse vitorioso da competição receberia um aporte de investimentos do governo federal, além de ter a economia local impulsionada pelos setores da construção civil e do turismo.

A competição para ser a cidade sede se acirrou entre Nova York e Chicago, quando Saint Louis acordou em receber a Exposição de 1904. (EVERDELL, 2000, p. 243-266) Chicago venceu a disputa no Congresso em março de 1890. A cidade contou com a ajuda financeira e influência política de seus maiores financistas e industriais, como Philip Armour (dono do frigorífico Armour), Potter Palmer (empreendedor do ramo imobiliário), George Pullman (magnata do transporte ferroviário), Marshall Field (empresário de lojas de departamento). (MUCCIGROSSO, 1993, p. 13-47) Quase todos os citados tiveram alguma participação direta na organização do evento, alguns até mesmo como diretores da Exposição.

Parte importante do Partido Republicano também apoiava o intento de Chicago. Entre esses políticos estavam o então presidente Benjamin Harrison e o Secretário de Estado James Blaine, famoso por articular a conhecida política do Pan-americanismo. ${ }^{4}$

\footnotetext{
${ }^{4}$ O Partido Republicano dominou o cenário político do final da Guerra Civil (1861-1865) até as primeiras décadas do século XX, carregando as bandeiras da Reconstrução e da industrialização do país. (REICHLEY, 1992, p. 140) O Pan-americanismo foi uma política externa norte-americana que visava o
}

\section{CANPHLAC}

Revista Eletrônica da ANPHLAC, ISSN 1679-1061, №. 22, p. 147-181, Jan./Jun., 2017.

http://revista.anphlac.org.br 
Foram os membros desse mesmo Partido que assumiram os cargos mais importantes na comissão da Exposição, como o Senador de Michigan Thomas Palmer (Presidente da Comissão) e o Congressista de Illinois George Davis (Diretor Geral da Exposição). Apesar de ser apresentada como uma iniciativa nacional, a Exposição foi uma realização comandada por empresários e políticos de Chicago, bem como por membros ou simpatizantes do Partido Republicano, especialmente aqueles que fizeram sua trajetória política nos estados do Oeste.

A vitória de Chicago sobre Nova York não foi bem digerida por veículos da imprensa e empresários nova-iorquinos que chegaram a cogitar um boicote ao evento. Mesmo os jornais republicanos da cidade aderiram a uma "campanha" não oficial de difamação da Exposição, espalhando notícias de corrupção, atrasos e desencontros da organização. Os periódicos de Chicago, por sua vez, responderam as alegações com editoriais afiados e charges, que caracterizavam Nova York como uma cidade que não sabia perder.

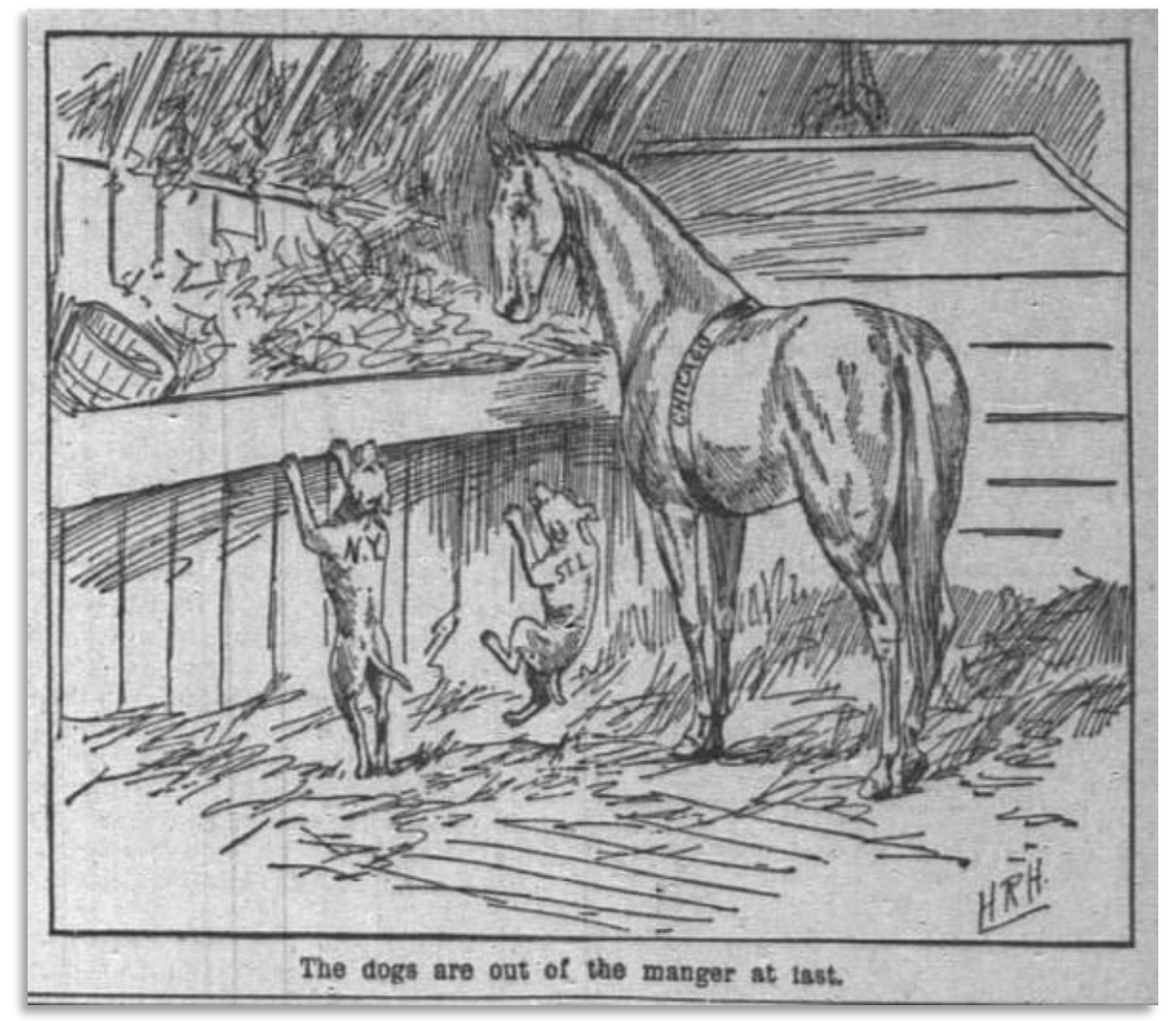

Imagem 6 - Charge de The Chicago Tribune do dia 26 de março de 1890. Nela, dois cachorros, um representando Nova Iorque e o outro, Saint Louis, tentam alcançar o cavalo, que leva grafado "Chicago"

estreitamento dos laços comerciais, políticos e culturais com os demais países das Américas. A ideia de um continente unido também esteve presente na Exposição de Chicago, conforme eu analiso em minha pesquisa de Mestrado (GIMENES, 2016).

\section{GANPHLAC}

Revista Eletrônica da ANPHLAC, ISSN 1679-1061, №. 22, p. 147-181, Jan./Jun., 2017. 
na faixa que envolve seu corpo. A legenda do cartoon, "Os cachorros estão fora da manjedoura finalmente", fazia referência à fábula de Esopo "O cachorro na manjedoura", na qual dois cães egoístas tentam monopolizar o uso do estábulo, mesmo esse não possuindo nenhuma utilidade para eles.

Essa disputa regional entre as duas metrópoles foi muito significativa no final do século XIX, tendo sido bastante agravada pela escolha da sede da Exposição. No Oeste dos Estados Unidos, intelectuais passaram a conclamar a independência cultural e a originalidade norte-americana dos western states em relação à Costa Leste. (HOFSTADTER, 1969, p. 47-83) Chicago passou a ser vista por muitos desses intelectuais como o centro do Oeste, entendido aqui não como um território geográfico, e sim como um espaço imaginário que abrigava os estados que não faziam parte originalmente das treze colônias britânicas continentais.

Em junho de 1893, o norte-americano Frederick Turner apresentou sua "tese da fronteira" em um simpósio de História na Exposição Universal de Chicago. O paper de Turner - um verdadeiro manifesto western - tornou-se uma das explicações mais dominantes sobre a História dos Estados Unidos durante boa parte do século XX. (AVILA, 2006, p. 10) Em linhas gerais, o historiador acreditava que a expansão territorial para o Oeste era fundamental para compreender o desenvolvimento do país. Turner discutia com correntes que explicavam a origem dos Estados Unidos na Europa, ou no embate entre o Norte e o Sul. Na visão desse autor, as instituições norteamericanas ter-se-iam moldado durante o avanço para o Pacífico, a fim de vencer o ambiente hostil dessas localidades. O contato de populações com as condições desfavoráveis do Oeste teria sido essencial na formação do caráter dos norteamericanos. (TURNER, 1992)

\section{O papel dos cientistas na Exposição}

Não foi só de conflitos e de jogos políticos que a Exposição foi montada: a ciência e as instituições acadêmicas atuaram decisivamente na orientação dos rumos do evento. O Smithsonian Institution, um dos mais importantes estabelecimentos de ensino e pesquisa científica do país, foi fundamental na discussão sobre a classificação e distribuição das exibições da Exposição de Chicago. Tendo em vista a ambiciosa

\section{GANPHLAC}


pretensão de ser universal, o evento foi dividido em quinze departamentos, cada qual comandado por um especialista:

\begin{tabular}{|c|c|}
\hline A - Agricultura e Alimentação & $\mathbf{J}$ - Eletricidade \\
\hline B - Horticultura e Floricultura & $\mathrm{K}$ - Belas Artes \\
\hline $\begin{array}{l}\mathrm{C} \text { - Pecuária (Animais domésticos e } \\
\text { selvagens) }\end{array}$ & L- Artes liberais (Literatura, Música) \\
\hline D - Peixes e pesca & M - Etnologia \\
\hline E - Minérios, mineração e metalurgia & $\mathrm{N}-$ Floresta \\
\hline $\mathrm{F}$ - Maquinaria & O - Propaganda e Promoção* \\
\hline $\begin{array}{l}\text { G - Transportes (Ferrovias, } \\
\text { embarcações e veículos) } \\
\text { H - Manufaturas }\end{array}$ & $\begin{array}{l}\mathrm{P} \text { - Relações Internacionais } \\
* \text { O Departamento O será analisado em detalhes } \\
\text { mais à frente. }\end{array}$ \\
\hline
\end{tabular}

Tabela 1- Classificação das exibições (HANDY, 1893, p. 29-30)

O objetivo era abarcar todas as atividades humanas e os conhecimentos sobre o globo. Esse intuito enciclopedista era herdeiro direto da história natural e dos sistemas classificatórios das espécies do século XVIII. Segundo Mary Louise Pratt, a ação humana de estudar, classificar e distribuir o mundo em categorias foi responsável por consolidar uma "consciência planetária" dos europeus (e norte-americanos), que passaram a se preocupar em conhecer o outro, a partir de ordenações eurocêntricas. (PRATT, 1999, p. 35; 41-75) Foi dentro desse contexto que circulou na Europa uma grande quantidade de textos e imagens sobre outros países e povos, como romances, notícias de jornais e relatos de viagem - muitos destes, produzidos pelos próprios naturalistas. Todo esse arcabouço de conhecimento foi responsável por forjar uma falsa percepção sobre o mundo não europeu, materializada na criação de estereótipos que reduziam a importância de outras culturas e, em certa medida, justificavam as intervenções imperialistas das nações europeias e dos Estados Unidos. As exposições

\section{GANPHLAC}


universais, apesar de serem fenômenos posteriores a esse primeiro impulso para a constituição de um saber total, fizeram parte desse mesmo processo.

A principal mente científica na organização da Exposição de 1893 foi o ictiólogo George Goode, que, à época, fazia parte dos quadros do Smithsonian Institution e dirigia o Museu Nacional de História Natural. Ele foi responsável por esboçar o sistema de classificação exposto acima. Na opinião dele,

O espírito da exibição proposta era o de mostrar a história do nosso continente desde a ocupação europeia e a sua influência sobre a história do mundo. É também expor, tanto quanto for possível, as etapas do progresso da civilização e de suas artes em séculos sucessivos, e em todos os lugares até o presente momento e a presente condição; para ser, na verdade, uma enciclopédia ilustrada da civilização. É ser tão generoso em seu escopo que seus restos pictóricos e literários sejam preservados como o melhor registro da cultura humana na última década do século XIX. (GOODE, 1893, p. 654) [Tradução e destaques meus]

A colocação acima expressa a consciência de uma elite letrada do final do século XIX, não apenas norte-americana, que estava imbuída de uma crença na razão e na certeza do progresso. Como muitos de seus pares, George Goode compartilhava das teorias do evolucionismo social que sustentavam que as sociedades se desenvolviam de um estado primitivo para um estágio civilizado. Essas categorias do evolucionismo foram decisivas na distribuição das exibições no Jackson Park. É interessante destacar também a preocupação do cientista em relação aos registros que seriam deixados pela Exposição, um cuidado que, como veremos, foi compartilhado por outros organizadores.

\section{A arquitetura de contrastes da Exposição}

O espaço da Exposição foi dividido em dois segmentos diferentes. O Midway Plaisance era um longo corredor, onde os povos considerados não civilizados foram agrupados; ali estavam os pavilhões da China e de países africanos, além de exibições esparsas de árabes e índios norte-americanos. Esse mesmo lugar era compartilhado por pavilhões históricos que representavam as nações europeias em séculos passados. O Midway Plaisance era, portanto, o espaço associado ao "atraso" e ao "primitivo".

\section{GANPHLAC}




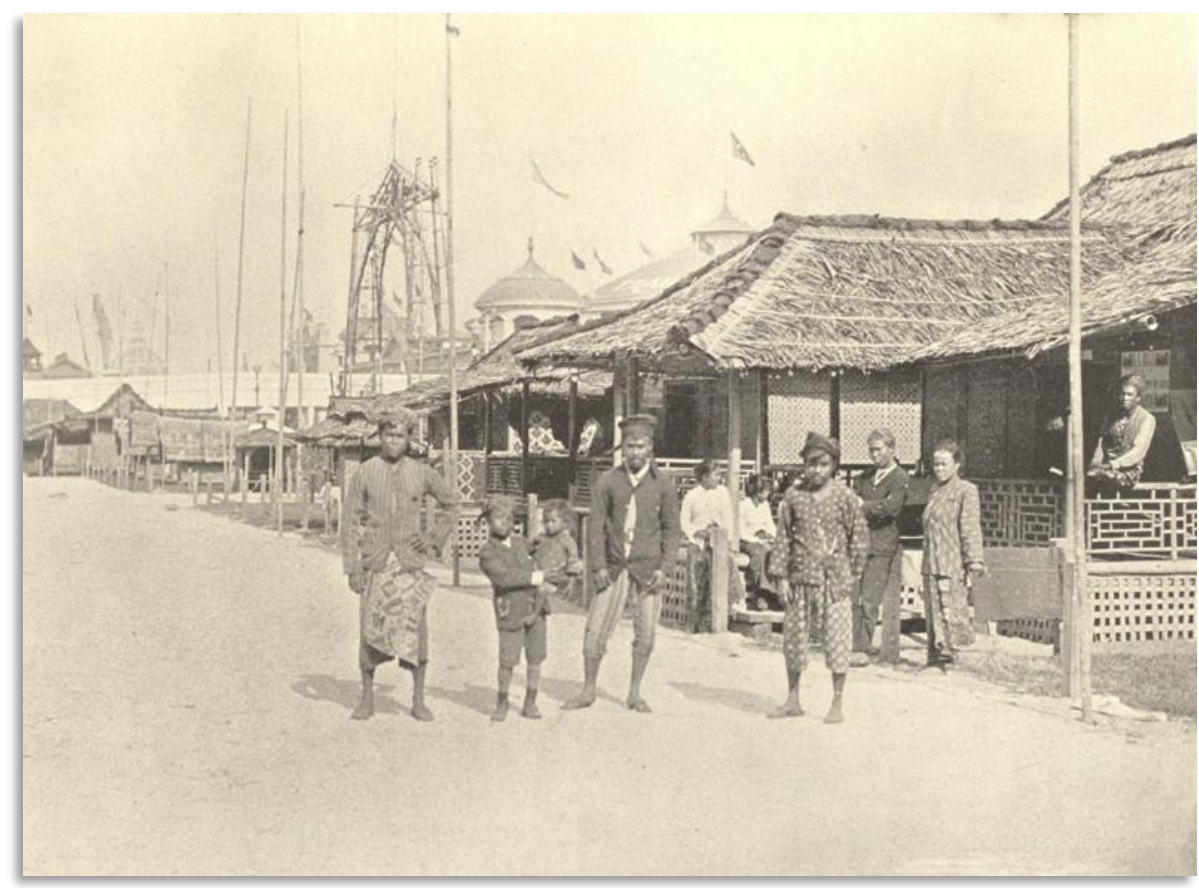

Imagem 7 - Fotografia da Exibição "Javanese Village", no Midway Plaisance. Muitos dos nativos presentes nessas exibições do Midway Plaisance eram atores contratados por companhias de entretenimento. Fotografia de C. D. Arnold, republicada no livro Shepp's World's Fair Photographed, p. 493.

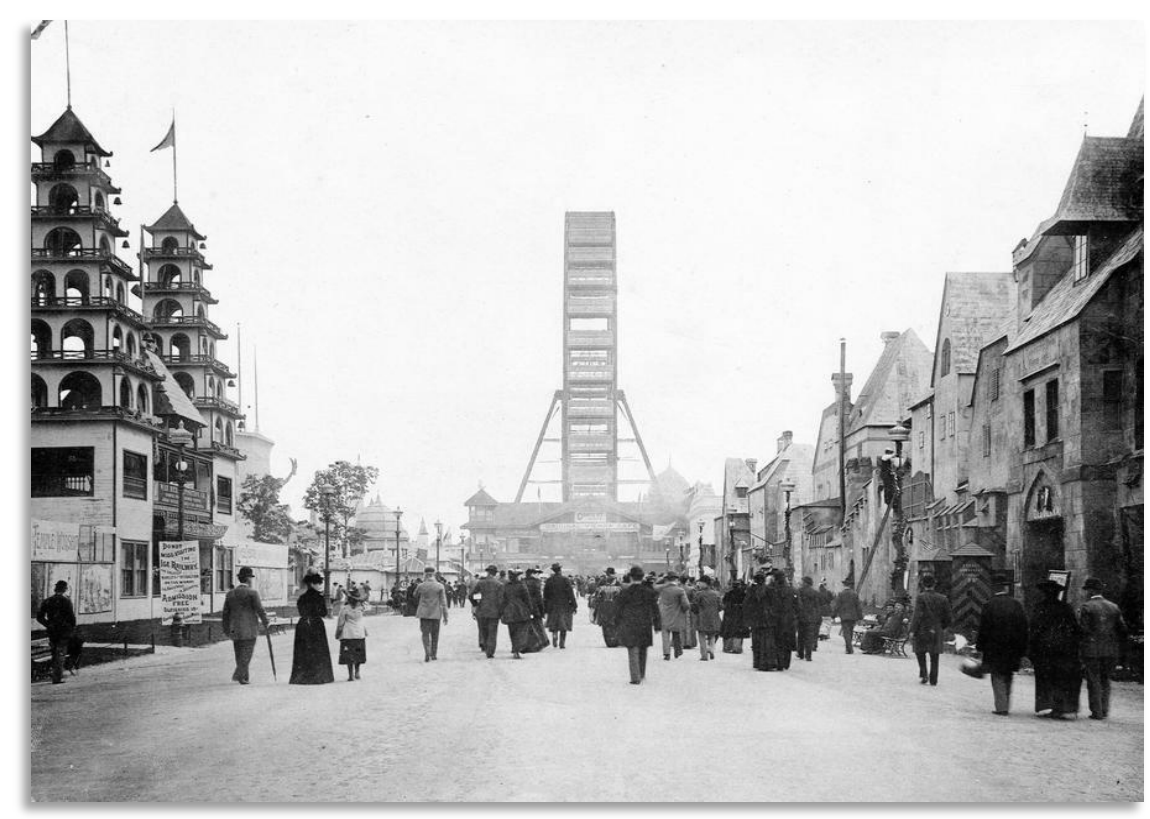

Imagem 8 - Fotografia do corredor do Midway Plaisance. Nela é possível avistar a imensa roda gigante, com 80 metros de altura. Do lado esquerdo, está o teatro chinês, onde artistas faziam performances. Do lado direito, estão construções que remontam os antigos vilarejos alemães. Fotografia de C. D. Arnold em platinotipia (acervo da Chicago Historical Society).

\section{GANPHLAC}

Revista Eletrônica da ANPHLAC, ISSN 1679-1061, №. 22, p. 147-181, Jan./Jun., 2017. http://revista.anphlac.org.br 
Todos os visitantes que chegavam ao evento por meio de trens precisavam percorrer essa área para chegar à outra parte da Exposição, a White City. A cidade branca, nome em referência aos prédios cobertos de gesso, reunia as exibições dos Estados Unidos e todos os países considerados civilizados pelos organizadores. Não é possível ignorar o fato de que a White City também fazia alusão aos brancos norteamericanos, visto que os Estados Unidos passavam por um intenso processo de segregação racial. Diversos grupos negros fizeram denúncias a respeito do caráter segregacionista da Exposição, que os excluíam da história norte-americana e os caricaturavam como indivíduos de segunda classe. Frederick Douglass e Ida Wells, precursores dos movimentos por Direitos Civis e Econômicos, publicaram panfletos sobre a situação do negro na América e distribuíram pelo evento. Este movimento incitou a recomendação de um comissário negro para a Exposição e a proposição de um dia de comemoração reservado aos negros, o Colored People's Day. Ida Wells, diferentemente de Douglass, que aceitou ser o representante do Haiti, percebeu a segregação que este dia impunha e pediu aos negros que boicotassem a Exposição. (RYDELL, 1999, p. 29-43)

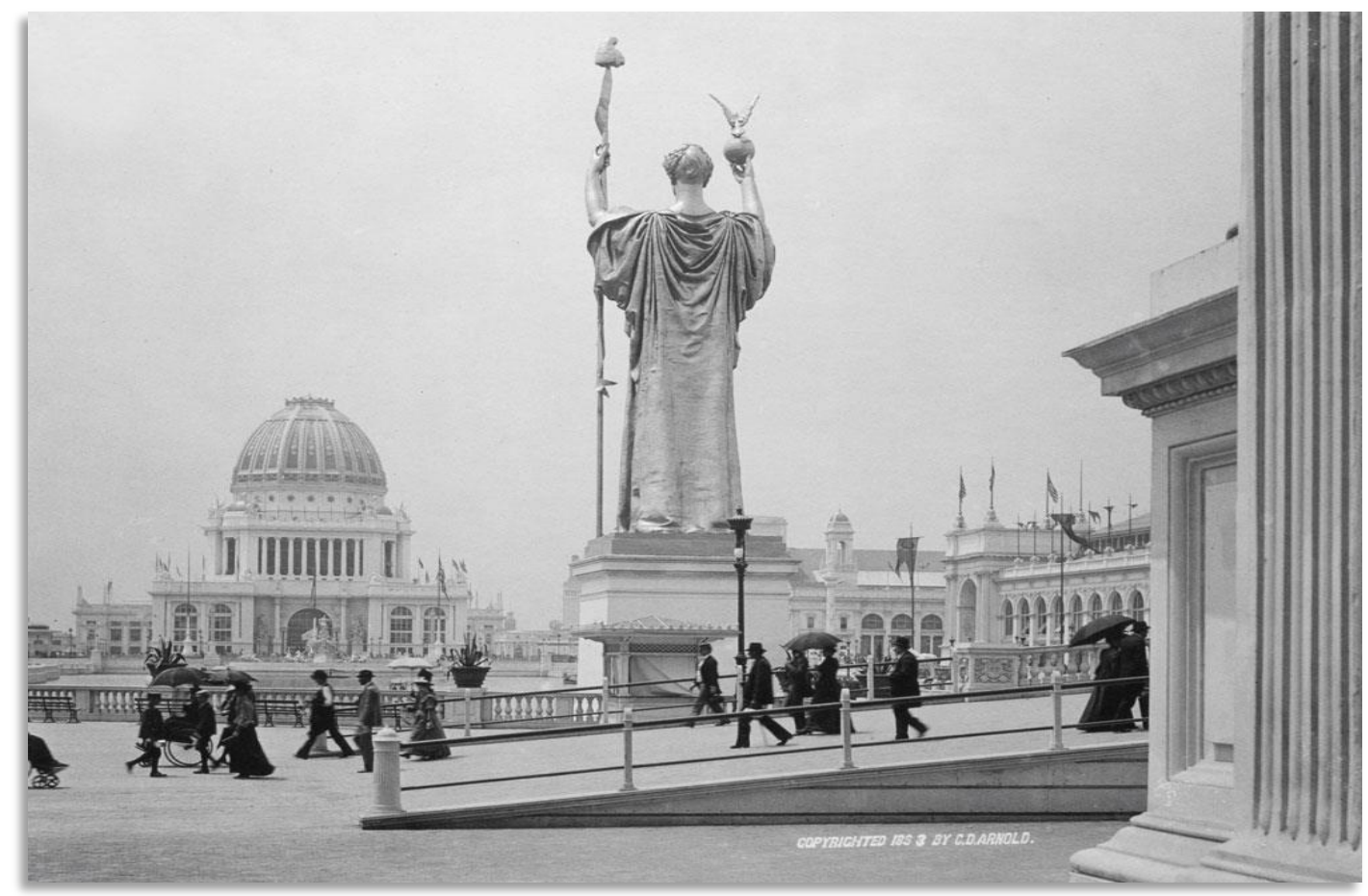

Imagem 9 - Vista geral da White City. A fotografia oferece indícios sobre as dimensões e aspectos da White City. Ao fundo da imagem está o Administration Building, utilizado para abrigar a administração do evento e seus organizadores. O prédio tinha cerca de 80 metros de altura, considerando a sua abóbada. No centro da imagem é possível perceber a gigantesca estátua de Columbia, a alegoria feminina da República; essa figura grandiosa segurava um globo em suas mãos, onde repousava uma águia — figura

\section{GANPHLAC}

Revista Eletrônica da ANPHLAC, ISSN 1679-1061, №. 22, p. 147-181, Jan./Jun., 2017.

http://revista.anphlac.org.br 
que simboliza os Estados Unidos. No lado direito da fotografia, está o prédio das Manufaturas, que à época foi considerado a maior construção do mundo, com cerca de $160.000 \mathrm{~m}^{2}$. Essa edificação trazia exibições sobre os avanços tecnológicos de cada nação. Fotografia de C. D. Arnold em platinotipia (acervo do Field Museum).

A White City era um espaço imagético completamente distinto do Midway Plaisance. O corredor era lembrado por sua arquitetura pitoresca, pelas dançarinas do ventre, pelos homens que cuspiam fogo, pelos índios que davam autógrafos e pela imensa roda gigante - a primeira do mundo, que se iluminava à noite, construída como resposta à Torre Eiffel da Exposição de Paris de 1889. Em outro lugar, a poucos metros dali, foram erguidos prédios brancos gigantescos ao estilo neoclássico, alguns com mais de 80 metros de altura, estátuas pintadas de dourado, uma grande bacia d'água, onde gôndolas transportavam os visitantes ao melhor estilo veneziano. A ideia de contraste não pode ser aqui ignorada: um espaço de diversão, de entretenimento, associado ao inusitado e o outro de admiração, de respeito ao passado, mas que trazia as maravilhas do mundo moderno.

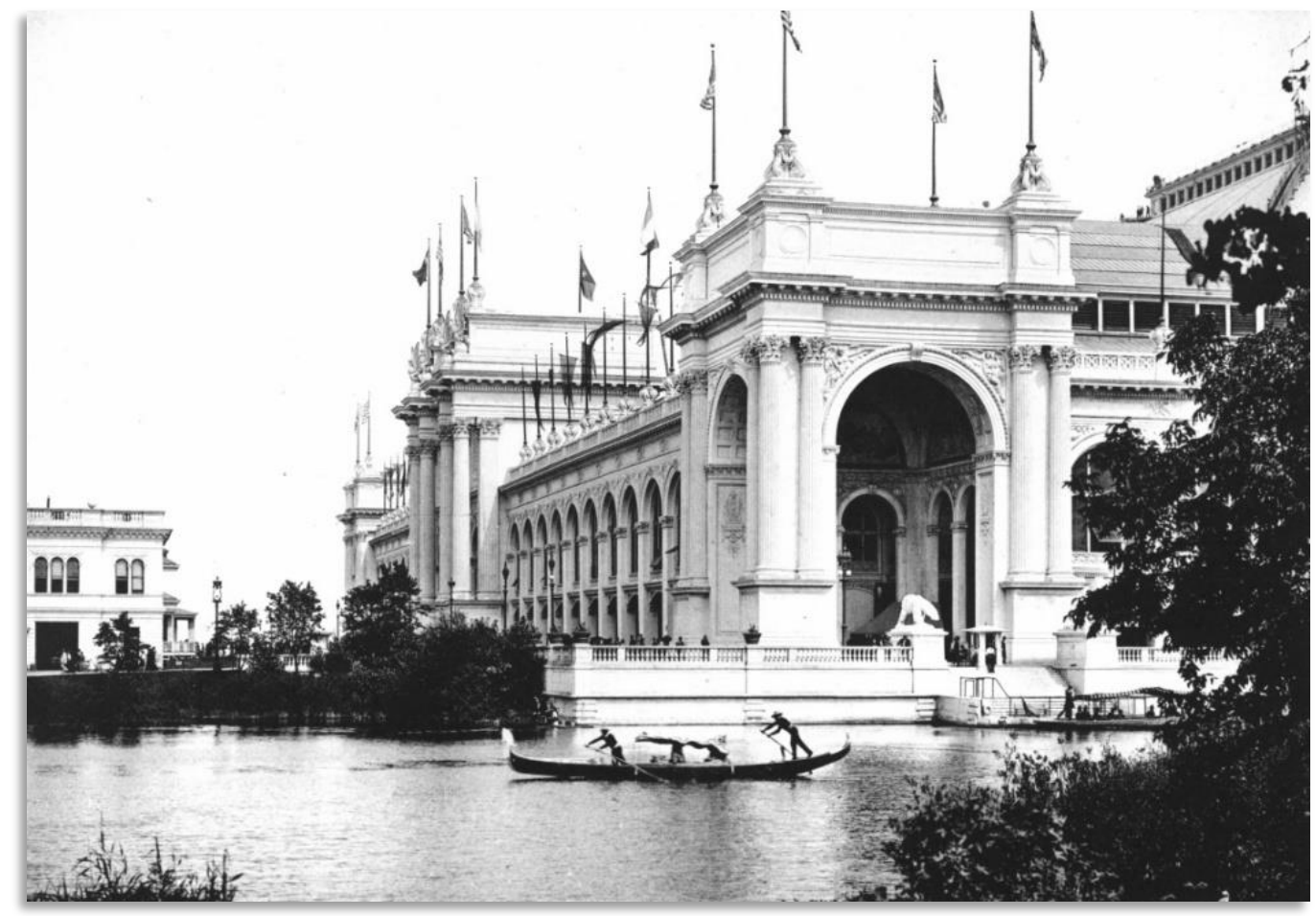

Imagem 10 - Gôndolas na White City. No centro da imagem está o prédio de Artes Liberais. Logo abaixo, é possível visualizar a bacia d'água e um barco que transportava os visitantes da Exposição. Fotografia de C. D. Arnold em platinotipia, reproduzida no álbum Official Views of the World's Columbian Exposition, plate 2 .

\section{GANPHLAC}

Revista Eletrônica da ANPHLAC, ISSN 1679-1061, №. 22, p. 147-181, Jan./Jun., 2017.

http://revista.anphlac.org.br 
Esses contrastes ganhavam nitidez quando o espectador observava a Exposição do topo da imensa roda gigante construída no meio do corredor da Midway Plaisance. A atração inventada por George Ferris possibilitava a homens e mulheres uma experiência visual inédita. $\mathrm{Na}$ medida em que a roda girava e a cabine subia, uma imagem panorâmica se compunha, na qual era possível observar em um primeiro plano o Midway Plaisance e suas edificações simples, "exóticas" e, em segundo momento, a White City e seus prédios suntuosos.

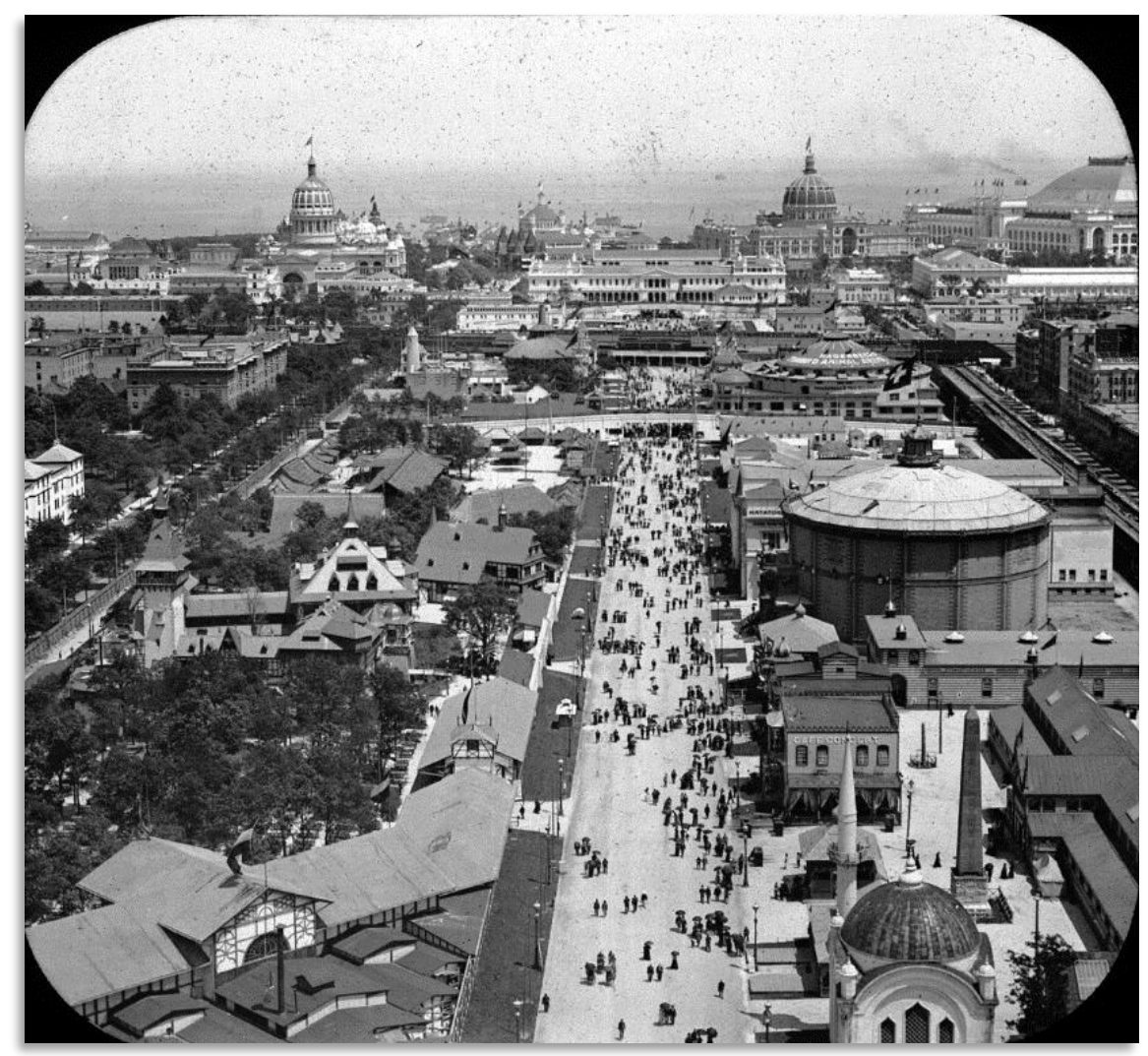

Imagem 11 - Visão da roda-gigante. Foto tirada do topo da Ferris Whell pelo fotógrafo amador Starks W. Lewis para projeção em lanternas mágicas (slides de vidro). Deste ponto de vista, o contraste entre o Midway Plaisance (corredor) em primeiro plano e a grandiosidade da White City ao fundo era flagrantemente percebido (coleção World's Columbian Exposition lantern slides do Brooklyn Museum, $\mathrm{n}^{\circ}$ 50).

O exótico, segundo Edward Said, "substitui a marca do poder pelos afagos da curiosidade" e coloca uma barreira intransponível entre quem faz o discurso e quem é representado. (SAID, 2011, p. 218) As exposições europeias, como a da Paris de 1889, costumeiramente traziam modelos de aldeias e nativos de suas colônias. Era como se

\section{GANPHLAC}

Revista Eletrônica da ANPHLAC, ISSN 1679-1061, №. 22, p. 147-181, Jan./Jun., 2017.

http://revista.anphlac.org.br 
quisessem reproduzir um microcosmo de seu domínio imperial em uma encenação que reduzia culturas milenares a estereótipos e justificava as ações imperialistas do final do século XIX. Assim como em Chicago, essas exibições eram subordinadas a um espaço secundário em relação às atrações principais.

A adoção do estilo neoclássico da White City para um evento que celebrava a novidade é bastante significativa, ainda mais se consideramos que o centro comercial reconstruído de Chicago era associado ao que havia de mais funcional e tecnológico do período, designando até mesmo uma nova tendência arquitetônica, a Escola de Chicago. (CONDIT, 1964, p. 26-94) Daniel Burnham, o arquiteto da Escola de Chicago e responsável pela cidade branca, acreditava que:

\footnotetext{
A influência da Exposição na arquitetura inspirará uma reversão para o ideal puro dos antigos. Nós estamos em um período inventivo, e já tivemos desprezo suficiente pelos clássicos. Homens desenvolvem novas ideias e imaginam que podem começar uma nova escola sem muita referência ao passado. (...) Chicago é como Atenas foi. Como o alicerce de grande atividade em um tempo passado, as nações fortes e independentes do mundo afluíam para aquela cidade. O que foi verdade para Atenas a esse respeito é agora verdade para Chicago. As condições estão todas aqui para o triunfo comercial, intelectual e artístico, e a Exposição, em sua fascinante beleza, destaca-se como evidência desse fato. (BURNHAM, 1893, p. 9) [Tradução minha]
}

A arquitetura é uma vontade de expressão por meio da qual muitas mensagens podem ser transmitidas. Buscando sua força nos valores e virtudes da Grécia Antiga e do Império Romano, a estética neoclássica foi recuperada em diversos momentos da história contemporânea como forma de demonstração de poder — por exemplo, durante o período Napoleônico na França (1799-1815). No excerto acima, Burnham associou Atenas a Chicago, como se a metrópole dos Estados Unidos passasse a ocupar a posição central que a cidade grega um dia desfrutara no mundo mediterrâneo e como berço da civilização ocidental.

\section{GANPHLAC}




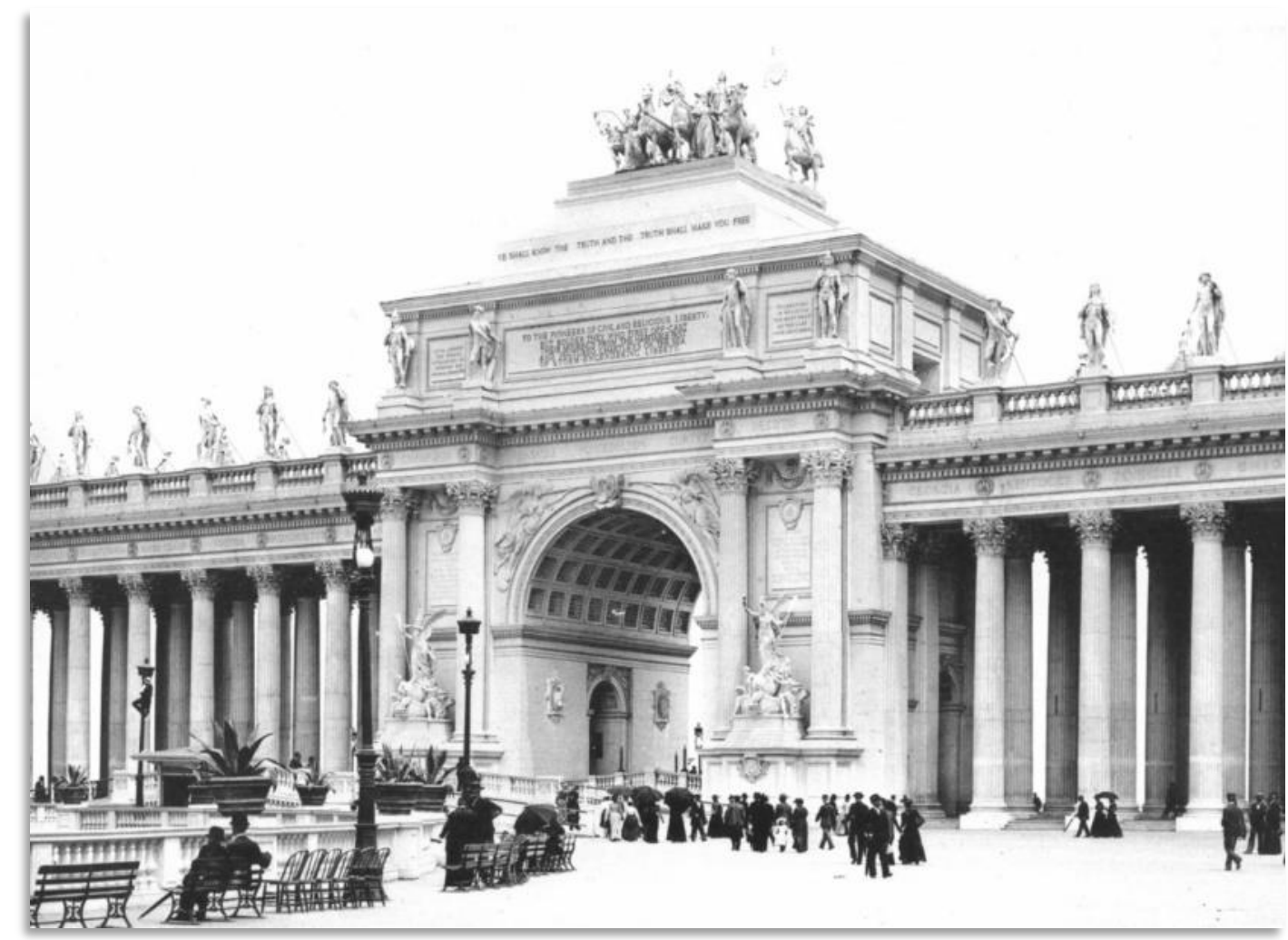

Imagem 12 - Fotografia do Arco, Peristilo e da Quadriga, estátua localizada acima da estrutura que representa uma carruagem romana puxada por quatro cavalos. Essa construção faz alusão aos arcos do triunfo do Império Romano e também de Paris. Arnold costumava fotografar as atrações da Exposição antes dos portões abrirem, mas escolheu incluir pessoas nessa composição, justamente para que elas servissem como ponto de referência para as dimensões do Arco. Fotografia de C. D. Arnold em platinotipia, reproduzida no álbum Official Views of the World's Columbian Exposition, plate 13.

O contraste entre a "civilização" e o "primitivo" colocado pela Exposição cumpria com o objetivo de demonstrar as vantagens do progresso para seus visitantes. Se os Estados Unidos representavam o ápice do desenvolvimento humano, comparáveis às demais nações europeias, não havia motivos para questionar a realidade social ou propor outros meios para o progresso. (RYDELL, 1984, p. 38-71) Mais do que isso, parte do processo evolucionário consistia em exibir e levar os valores democráticos e republicanos aos demais países e povos - uma perspectiva tipicamente imperial.

\section{Representações imagéticas da Exposição de Chicago}

As exposições universais eram acontecimentos predominantemente visuais. (BARBUY, 1999, p. 17-27) Na ambição de recriarem o mundo em miniatura e de apresentarem a história dos Estados Unidos e de Chicago, os organizadores do evento

\section{GANPHLAC}

Revista Eletrônica da ANPHLAC, ISSN 1679-1061, №. 22, p. 147-181, Jan./Jun., 2017.

http://revista.anphlac.org.br 
de 1893 se apoiaram largamente em representações — algumas delas escritas, mas uma boa parte de natureza imagética. Quando decidiram iluminar a Exposição à noite, por exemplo, a intenção não era apenas apresentar uma nova tecnologia, como também seduzir, maravilhar e encantar o espectador - era mostrar visualmente que os Estados Unidos haviam alcançado um patamar de desenvolvimento científico e industrial, que lhes permitia caminhar ao lado das grandes potências europeias.

A própria distribuição espacial da Exposição, que dividia os povos do globo entre "menos evoluídos" e mais "civilizados", autorizava a construção de uma narrativa em etapas sobre a história da humanidade. Para o jornal The Chicago Tribune, principal veículo de imprensa da região dos Grandes Lagos, a Exposição de 1893 permitia aos visitantes uma comparação com as demais nações do mundo:

\footnotetext{
Que grande oportunidade foi concedida ao espírito científico de acompanhar uma espiral da evolução, encontrando a humanidade em suas mais altas fases até quase suas animalescas. Nítidos contrastes foram oferecidos a respeito dos costumes de diferentes povos. (THE CHICAGO TRIBUNE, 1 de nov. de 1893, p. 9) [Tradução minha]
}

Uma questão interessante sobre a história visual da Exposição de Chicago diz respeito à circulação de gravuras e fotografias. Centenas de materiais, como reportagens, guias, álbuns, panfletos e souvenires, foram elaborados sobre o evento. Entretanto, os repertórios visuais dessas produções são esteticamente parecidos, ou até mesmo idênticos. A explicação para esse fato inusitado está no controle exercido pelos organizadores sobre a produção de imagens da Exposição.

\section{GANPHLAC}



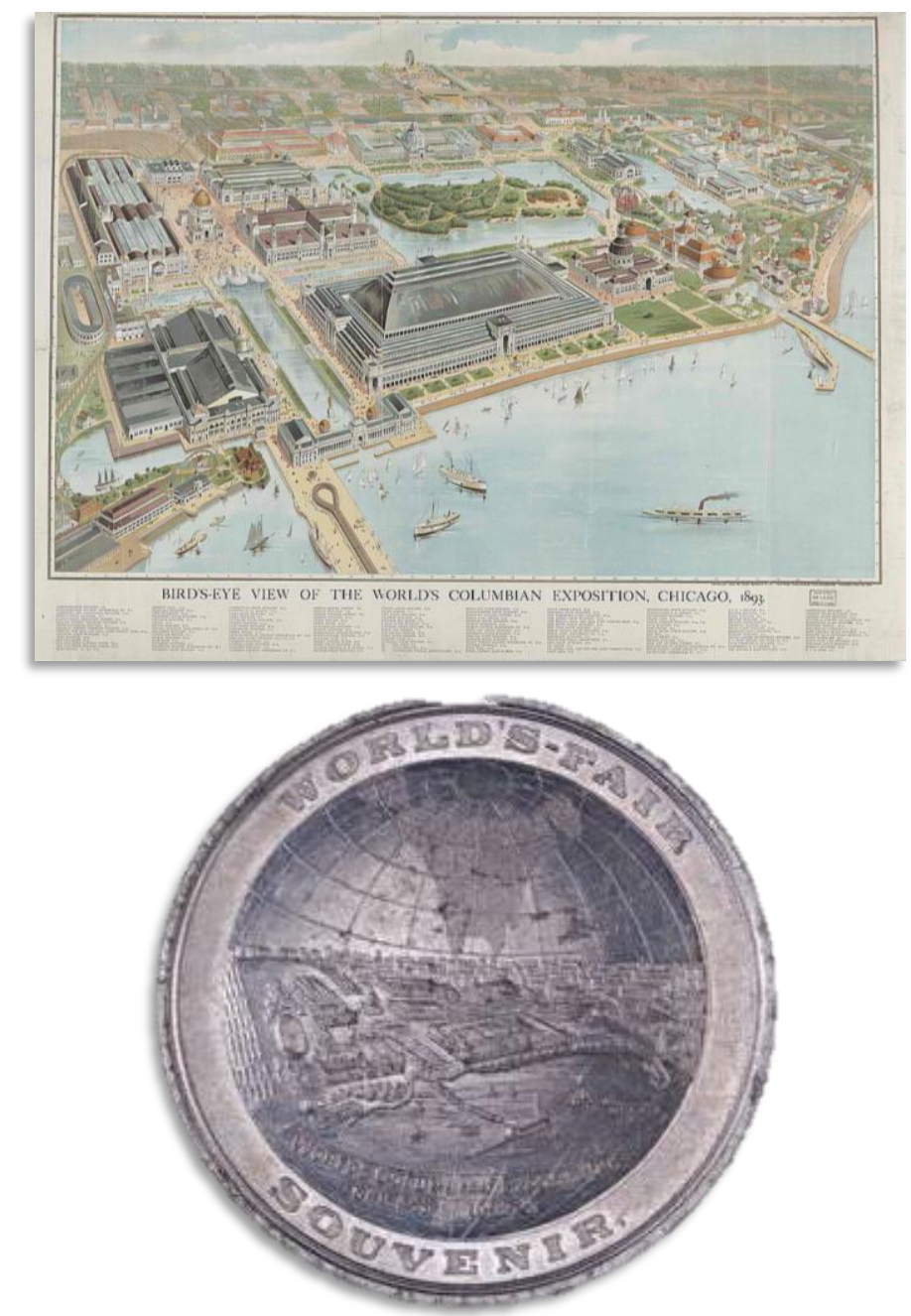

Imagem 13 - Acima, gravura sobre a distribuição dos prédios da Exposição, que foi amplamente difundida pelo Departamento de Propaganda e Promoção (acervo da Library of Congress). Abaixo, anverso da moeda-souvenir da Exposição, emitida em dezembro de 1891 (acervo pessoal); o mesmo mapa aparece talhado.

O primeiro departamento estabelecido durante os preparativos do evento foi o de Propaganda e Promoção (Departamento O, descrito na Tabela 1), responsável por promover a circulação de textos e gravuras. A sua criação sugere que o controle do discurso produzido sobre a Exposição de Chicago era fundamental desde o princípio. Corrobora essa afirmação, o fato de que o Departamento foi criado sob a justificativa de contornar as suspeitas que pairavam sobre a cidade e o evento. A propaganda negativa dos jornais nova-iorquinos, somada ao desconhecimento de muitos sobre Chicago, preocupava os organizadores. Apesar do convite oficial do governo dos Estados Unidos, a adesão inicial dos países estrangeiros foi considerada insuficiente. O Departamento de

\section{GANPHLAC}

Revista Eletrônica da ANPHLAC, ISSN 1679-1061, №. 22, p. 147-181, Jan./Jun., 2017.

http://revista.anphlac.org.br 
Estado decidiu enviar oficiais da U. S. Navy para a América Latina e Europa, além de mobilizar o corpo diplomático das embaixadas de alguns países. (GIMENES, 2016, p. 146-153) Empresários e cientistas norte-americanos também participaram desse esforço.

O Departamento de Propaganda e Promoção partilhava do mesmo objetivo: promover a Exposição entre os exibidores e a imprensa de nações estrangeiras. Comandava essa divisão, o experiente jornalista Moses Handy, que havia trilhado sua carreira em jornais de Nova York e Washington, além de ter comandado as campanhas presidenciais dos republicanos James Blaine (1884) e Benjamin Harrison (1888). Moses criou, nas palavras dele, "uma gigantesca agência de notícias", incumbida de enviar artigos, informações, panfletos, gravuras e litografias dos prédios da Exposição a editoras, jornais e revistas espalhados pelo mundo. Esses materiais poderiam ser publicados gratuitamente por esses veículos de comunicação. Segundo os dados do Departamento - números esses que sempre devemos questionar - esses textos e imagens foram enviados para cerca de 50.000 endereços, sendo que 20.000 deles eram publicações voltadas ao grande público, como periódicos e magazines, que poderiam replicar ou não a informação produzida pelo Departamento. (HANDY, 1893, p. 188) Metade do material produzido em inglês foi traduzido para outras línguas, entre elas, o espanhol, o francês e o alemão.

Além de enviar correspondências, o Departamento de Propaganda e Promoção mantinha arquivos sobre o que era publicado sobre a Exposição. As matérias sobre o evento, inclusive de países estrangeiros, eram catalogadas e se os funcionários encontrassem alguma incorreção ou equívoco significativo, solicitavam, por meio de cartas, a imediata retificação.

Durante a Exposição, o Departamento ocupou três andares do prédio da Administração. Em um desses andares, encontravam-se os jornalistas dos cinco maiores veículos de imprensa de Chicago. Esses periódicos colaboraram intimamente com essa seção, cedendo repórteres e ilustradores para a redação de artigos e elaboração de gravuras.

Por sua vez, as fotografias que circularam sobre a Exposição eram, em sua maioria, oficiais. Durante os preparativos, a organização do evento cedeu o monopólio das imagens fotográficas a dois profissionais: Harlow D. Higinbotham, filho do Presidente da Exposição de Chicago, e Charles Dudley Arnold. Os dois recebiam 2.000

\section{GANPHLAC}


dólares anuais de salários, o que equivale a 54.000 dólares hoje em dia (JOHNSTON, WILLIAMSON, 2015), além de um ganho de $10 \%$ sobre os lucros obtidos. Ao que tudo indica, era apenas C. D. Arnold, como gostava de assinar seus trabalhos, que efetivamente fotografava.

Naquela época, a fotografia era um negócio altamente lucrativo e os direitos sobre a imagem poderiam ser negociados com revistas e editoras a preços exorbitantes. Mas, em 1893, a câmera portátil da Kodak já era uma realidade que atormentava os negócios desses estúdios. Inventada em 1888, nos Estados Unidos, o equipamento foi conhecido por ser o primeiro voltado ao uso pessoal. (SANDLER, 2002, p. 20-21) Apesar de a câmera Kodak ser cara e a qualidade da imagem ser muito inferior às demais tecnologias da época, houve uma proibição da entrada de máquinas fotográficas no Jackson Park. Tal imposição resultou na apreensão de equipamentos e na aplicação de penalidades às pessoas que descumpriram a regra, como relataram os jornais de Chicago.

A proibição de fotografar não era total, pois os organizadores permitiam que máquinas fotográficas da Kodak fossem alugadas dentro da Exposição. O problema é que cada fotografia tirada por essas máquinas custava $\$ 5$, que equivaleriam hoje a $\$ 136$, dez vezes o valor de entrada na Exposição. Por conta disso, diversos jornais e revistas dos Estados Unidos se mostraram contrários à concessão do monopólio aos fotógrafos. Por utilizarem matérias-primas bastante onerosas, as fotografias de C. D. Arnold eram relativamente caras, chegando a custar entre $\$ 8$ a $\$ 40$ cada. Além do preço elevado, a fotogravura de platinotipias não era um processo fácil, o que acabou avolumando as reclamações. As publicações científicas também se queixavam da falta de negativos mais específicos, que deveriam enquadrar determinados equipamentos, por exemplo. Soma-se a todas essas questões o fato de Charles Dudley Arnold ter um temperamento forte, não permitindo que fossem abertas exceções às proibições sobre as câmeras fotográficas, nem mesmo a publicações científicas. Pessoalmente, Arnold apreendia as máquinas e mandava prender quem violasse as regras. Depois de algumas prisões e desentendimentos com a imprensa e com o Diretor Geral da Exposição, George Davis, Arnold foi afastado no último mês da Exposição. Seu nome foi deixado de lado nos relatórios oficiais.

\section{GANPHLAC}


Além de ser um negócio lucrativo, a fotografia também era um tipo de discurso e ter o controle sobre esse código estético era fundamental na definição da imagem dos países - lembrando que esse repertório visual circulou o mundo por meio de revistas e álbuns, que funcionavam como souvenires. Portanto, a restrição a máquinas fotográficas não foi imposta apenas por uma questão financeira, mas também como uma forma de controle da veiculação de imagens e dos discursos produzidos sobre a Exposição.

Entre todas as linguagens artísticas, a fotografia sempre foi considerada como aquela mais próxima da realidade, servindo muitas vezes como "ilustração" ou “documentação" dos fatos. (MAUAD, 2008, p. 31) Segundo Boris Kossoy, apesar da percepção de credibilidade, as imagens fotográficas contém em si realidades e ficções, sendo resultado de uma somatória de decisões do fotógrafo. (KOSSOY, 2009, p. 14) A produção fotográfica guarda uma relação intrínseca com a realidade (referente), própria desse sistema de representação, mas o faz por meio de filtros estéticos, culturais e técnicos que estão materializados nas escolhas dos assuntos, dos enquadramentos, dos momentos, dos equipamentos e substâncias reveladoras, e das composições das fotografias. (KOSSOY, 2009, p. 28 e 42) Durante o século XIX, tornaram-se comuns álbuns de fotos sobre determinadas temáticas - como as exposições universais - que contribuíram para uma leitura dirigida de cidades e países. (KOSSOY, 2009, p. 82; RYDELL, 1989, p. 118)

Estima-se que, em Chicago, foram produzidos mais de 15.000 negativos, muitos deles jamais veiculados. (BEWLEY, 2001) As imagens que efetivamente circularam foram reproduzidas em materiais impressos, como o álbum Official Views of the World's Columbian Exposition, produzido pelos fotógrafos oficiais da Exposição, e o livro Shepp's World's Fair Photographed, que recebeu autorização dos diretores do evento para ser publicado e que mesclava informações sobre as exibições e a história dos Estados Unidos com as fotografias.

Analisando os dois exemplares, é possível perceber a clara predominância de um elemento: a arquitetura dos prédios da White City. A escolha por Charles Dudley Arnold não foi ao acaso. Na verdade, o fotógrafo oficial era especialista em fotografias de arquitetura. (HALES, 1993) Durante a década de 1880, Arnold acumulou uma série de experiências em sua profissão fotografando cidades da Inglaterra, França e Estados Unidos. Em 1888, lançou o seu primeiro livro, intitulado Studies in Architecture at

\section{GANPHLAC}


Home and Abroad, que serviu como fonte de estudo para muitos arquitetos europeus e norte-americanos. O sucesso de seu livro e a qualidade de seus trabalhos levaram-no a trabalhar em Chicago já em 1891, documentando a construção da estrutura para a Exposição. Arnold também viria a se tornar o fotógrafo oficial da Exposição Panamericana de 1901.

A técnica utilizada por C. D. Arnold em suas fotografias era a platinotipia, um método dispendioso que demandava profundo conhecimento por parte do fotógrafo. Patenteado em 1873 pelo britânico William Willis, o processo fotográfico (de impressão) encontrou seu auge no final do século XIX, caindo rapidamente em desuso durante a Primeira Guerra, com o surgimento de novas tecnologias e o aumento considerável do valor da platina, que tornou seu emprego impraticável. (SANDLER, 2002, p. 59) O primeiro requisito da platinotipia era que o negativo deveria ter as mesmas dimensões da fotografia final. $\mathrm{O}$ grande negativo era então posicionado em cima de um papel de algodão de altíssima qualidade embebido uniformemente em uma solução de sal de platina. Esse tratamento do papel normalmente era feito através de um pincel. Assim, as marcas das pinceladas ficavam presentes no produto final, agregando um valor artístico ainda maior à fotografia. O negativo sobre a folha era então exposto a uma luz ultravioleta de intensidade alta e controlada. Após algumas horas, o conjunto era separado: o negativo era limpo e conservado e ao papel eram adicionadas, gradualmente, substâncias reveladoras como o oxalato de potássio. Depois de secas, as impressões estavam prontas. As fotografias obtidas através da platinotipia ganhavam linhas bem definidas e uma rica gradação tonal (múltiplos tons de cinza), conferindo muitas vezes um aspecto prateado às imagens. Se a intenção era criar as melhores representações possíveis sobre a Exposição, a técnica e os materiais escolhidos não poderiam ser mais adequados.

Arnold fotografou todas as fachadas de prédios da White City, muitas vezes utilizando enquadramentos conservadores: direção centralizada e nivelada, concentração média, o que sugere uma preocupação por parte dos organizadores do evento e do próprio fotógrafo em deixar registros sobre a arquitetura da Exposição. ${ }^{5}$ No entanto, seu

\footnotetext{
${ }^{5}$ Parte da análise das fotografias foi inspirada nos trabalhos da historiadora Ana Maria Mauad e em sua abordagem histórico-semiótica. (MAUAD, 1996, p. 79-98) O assunto, o enquadramento, a nitidez, a distribuição de planos, o arranjo/equilíbrio, a iluminação e a quantidade de pessoas foram as categorias consideradas para a análise dos álbuns.
}

\section{GANPHLAC}


repertório não consistia apenas de imagens objetivas das edificações e exibições. Arnold também produziu uma gama de fotografias de apreciável qualidade estética, com escolhas menos tradicionais de enquadramentos e a distribuição de três ou quatro planos em uma mesma imagem, todos em foco. O fotógrafo tinha acesso aos telhados dos prédios, o que lhe permitia englobar diversas atrações no Jackson Park em um mesmo panorama, passando uma impressão de grandiosidade à Exposição. Em quase todas as fotografias externas da White City, Arnold escolheu incorporar a bacia d'água, que refletia e direcionava os olhares para o assunto principal da imagem, que eram as edificações. No mundo ocidental, a água também simboliza a purificação e contribui para que os resultados finais das fotografias da cidade branca representem ideais de harmonia, virtude e perfeição.

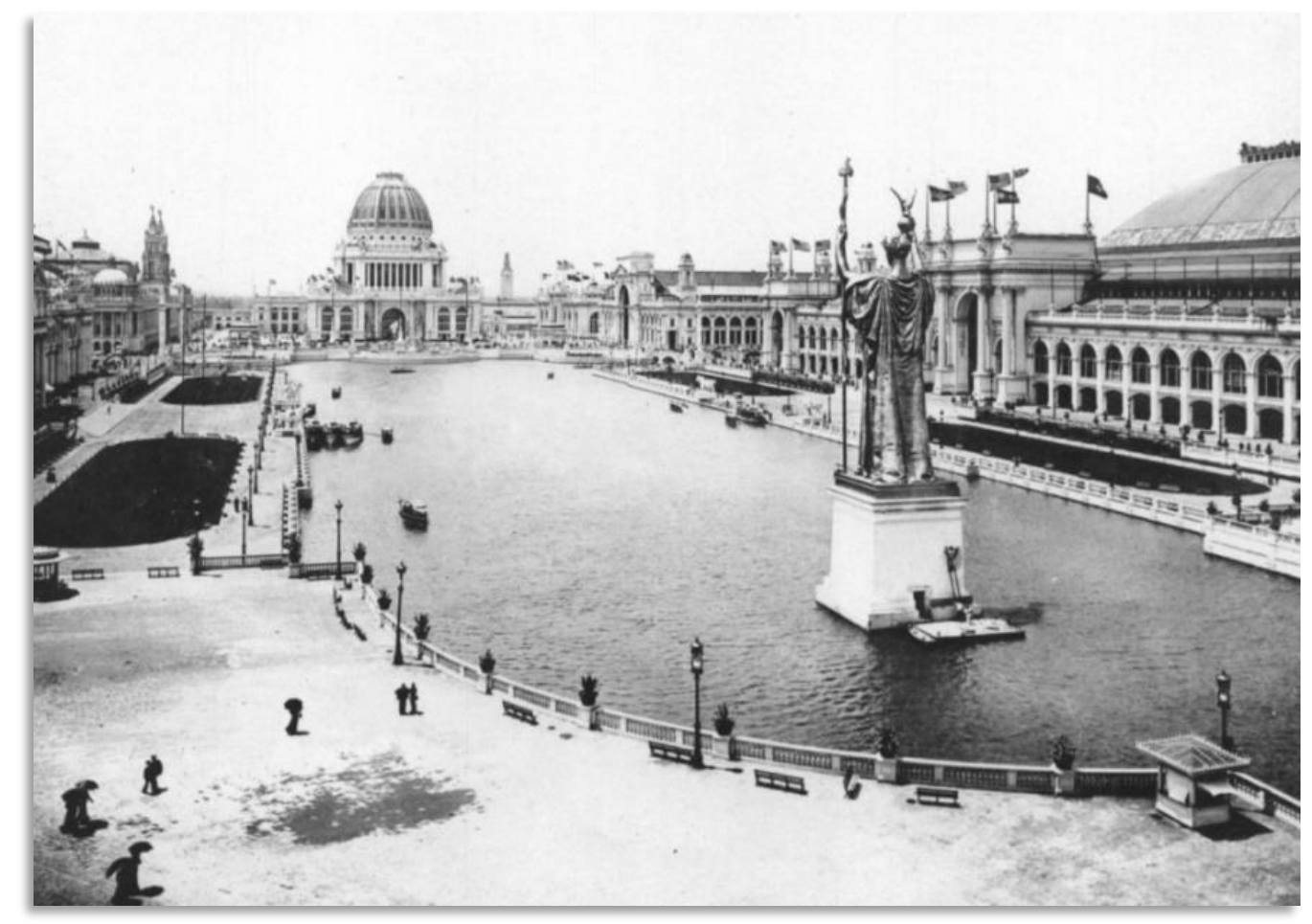

Imagem 14 - Fotografia tirada da cobertura de um prédio na White City. Nela, é possível avistar a grande bacia d'água, além dos prédios da Administração e de Agricultura. Fotografia de C. D. Arnold em platinotipia, reproduzida no álbum Official Views of the World's Columbian Exposition, plate 91.

No repertório visual de Arnold, as pessoas quase não apareciam. Quando se revelavam em suas fotografias, cumpriam três objetivos muito distintos entre si. Se surgissem em dezenas, tornavam-se um ponto de referência/comparação com as

\section{GANPHLAC}

Revista Eletrônica da ANPHLAC, ISSN 1679-1061, №. 22, p. 147-181, Jan./Jun., 2017. 
dimensões descomunais dos prédios da Exposição, novamente reafirmando a magnitude do evento (imagens 9 e 12). Se aparecessem em milhares - como uma multidão indistinguível - figuravam o sucesso de público em Chicago (imagem 15). Entretanto, se fossem retratadas individualmente ou em pequenos grupos, tornando-se o assunto principal da fotografia, era quase certo que a imagem fazia referência ao Midway Plaisance (imagens 7 e 16).

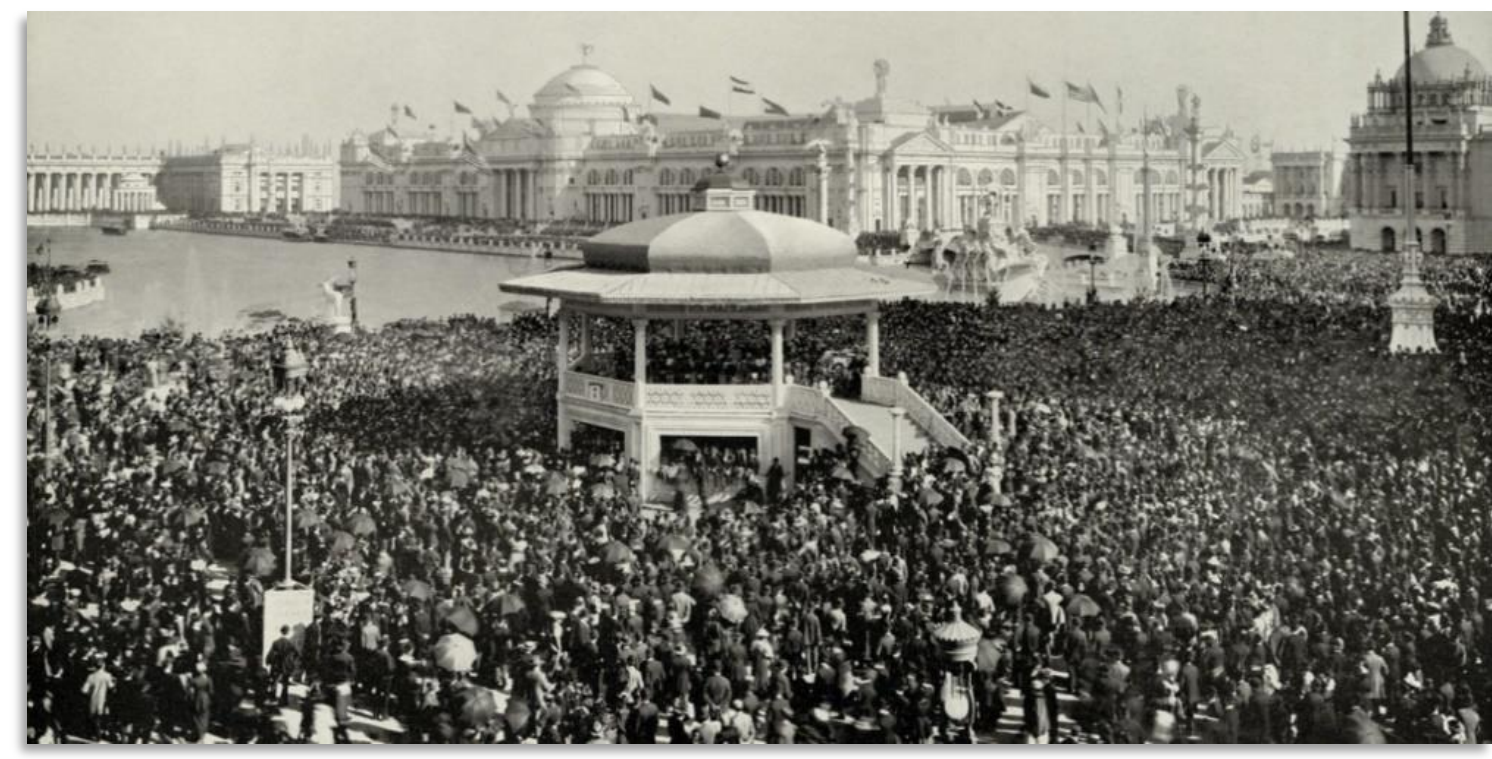

Imagem 15 - Arredores da White City em 09 de outubro de 1893, que foi a data escolhida para a celebração da cidade de Chicago na Exposição. O principal assunto da foto é a multidão. Estima-se que cerca de 700.000 pessoas visitaram o Jackson Park nesse dia. Ao fundo da fotografia é possível perceber o grande espelho d'água e o prédio de Agricultura. Fotografia de C. D. Arnold em platinotipia, acervo do Field Museum.

Não só as arquiteturas das duas áreas da Exposição eram completamente distintas entre si, como também as suas representações. Se classificarmos as fotografias da White City, grosso modo, como arquiteturais, podemos dizer que as imagens sobre o Midway Plaisance tinham um olhar etnográfico. Naquele grande corredor, Arnold também estava interessado em apreender os detalhes arquitetônicos do espaço, contudo, sua maior preocupação (assunto fotográfico) era enfatizar as fisionomias distintivas dos povos não ocidentais, baseando-se muitas vezes em critérios raciais — o que justificava sua escolha em fotografar aqueles exibidores, em especial, de perto.

\section{GANPHLAC}

Revista Eletrônica da ANPHLAC, ISSN 1679-1061, №. 22, p. 147-181, Jan./Jun., 2017.

http://revista.anphlac.org.br 


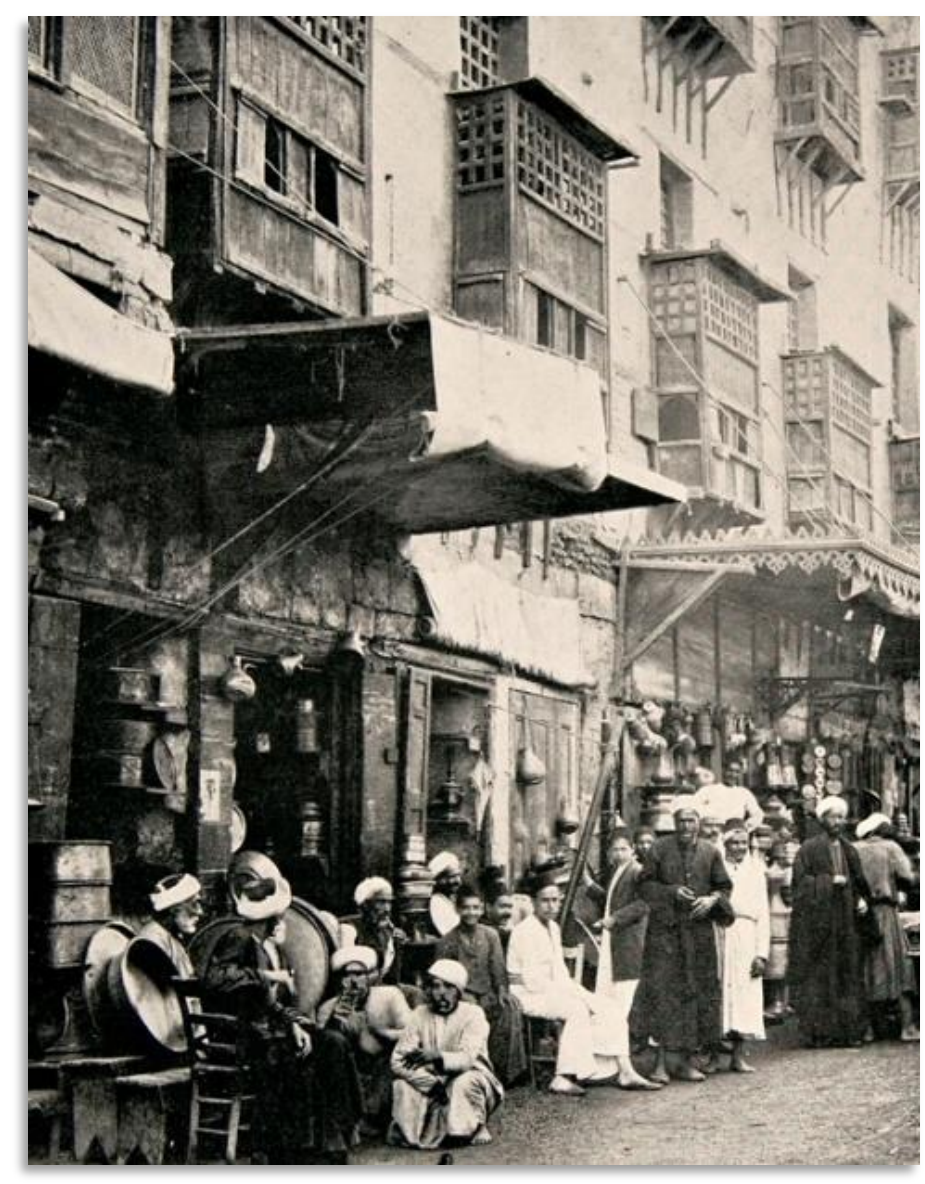

Imagem 16 - Exibição “Arabia” no Midway Plaisance. Nela, é possível perceber a preocupação de C. D. Arnold em captar os detalhes arquitetônicos, por exemplo, os muxarabiês, bem como os traços fisionômicos das pessoas que representavam os povos árabes. Fotografia de C. D. Arnold, republicada em BANCROFT, 1893, p. 62.

Segundo Edward Said, "o poder de narrar, ou de impedir que se formem ou surjam outras narrativas, é muito importante para a cultura e o imperialismo, e constitui uma das principais conexões entre ambos." (2011, p. 11) Ao escolher retratar os povos não ocidentais como culturalmente exóticos, tradicionais, à margem da civilização, e representar os países ocidentais, especialmente os Estados Unidos, como os detentores da virtude, do progresso, os mais evoluídos em uma "escala de humanidade", a mensagem, além de controlada, tornava-se clara. A excepcionalidade norte-americana foi forjada também a partir de relações de alteridade com o "outro".

O excepcionalismo dos Estados Unidos foi configurado a partir de uma série de dispositivos, em geral, míticos. Entre eles, destacam-se a noção de um povo eleito, missão e destino daquela sociedade, os mitos sobre o Oeste e a fronteira (JUNQUEIRA, 2000) — os dois últimos, particularmente, reiterados à exaustão na Exposição de

\section{GANPHLAC}

Revista Eletrônica da ANPHLAC, ISSN 1679-1061, №. 22, p. 147-181, Jan./Jun., 2017.

http://revista.anphlac.org.br 
Chicago. Foi essa mesma ideia de superioridade que alimentou, cinco anos depois, as intervenções militares sobre as ilhas de Cuba, Porto Rico, Filipinas e Guam.

A história da Exposição e suas fontes visuais são bastante intrigantes, especialmente no que diz respeito ao controle e difusão das imagens. Como vimos, o Departamento de Propaganda e Promoção funcionava como uma verdadeira máquina, instalada para mobilizar e influenciar a opinião pública a respeito da Exposição, da cidade de Chicago e também dos Estados Unidos. A fotografia, por sua vez, estava nas mãos dos organizadores do evento, que controlavam o uso dessa linguagem. A Exposição e, especialmente, o que foi escrito e reproduzido visualmente foi fundamental para alimentar a imaginação do norte-americano comum sobre si mesmo e o resto do mundo. Mais do que isso, o evento significou para muitos estrangeiros o primeiro contato a respeito do que seriam Chicago e os Estados Unidos modernos. O universo simbólico estabelecido propositalmente pelos organizadores da Exposição, que ligava o passado teoricamente triunfante de Colombo com o presente supostamente vitorioso dos Estados Unidos, também evocava um ideal de destino para os norteamericanos - o de se tornarem uma potência global.

\section{GANPHLAC}




\section{Fontes}

ARNOLD, Charles; HIGINBOTHAM, Harlow. Official Views of the World's Columbian Exposition. Chicago: Press Chicago Photo Gravure Co., 1893.

BANCROFT, Hubert. The Book of the Fair: an Historical and Descriptive Presentation of the World's Science, Art, and Industry, as Viewed Through the Columbian Exposition at Chicago in 1893. Chicago: The Bancroft Co., 1893.

GOODE, George. First Draft of a System of Classification for the World's Columbian Exposition - From the Report of U. S. National Museum, 1891. Washington: Government Printing Office, 1893.

SHEPP, James; SHEPP, Daniel. Shepp's World's Fair Photographed. Chicago: Globe Bible Publishing Co., 1893.

\section{Bibliografia}

AVILA, Arthur. E da fronteira veio um Pioneiro: a frontier thesis de Frederick Jackson Turner (1861-1932). Porto Alegre: Departamento de História, IFCH-UFRGS, 2006 (mimeo).

BAITZ, Rafael. Um continente em foco: a imagem fotográfica da América Latina nas revistas semanais brasileiras (1954-1964). São Paulo: Editora Humanitas FFLCH-USP, 2006.

BARBOSA, Carlos Alberto. A fotografia a serviço de Clio: uma interpretação da história visual de Revolução Mexicana (1900-1940). São Paulo: Editora Unesp, 2006.

BARBUY, Heloisa. A exposição universal de 1889 em Paris: Visão e representação na sociedade industrial. São Paulo: Loyola, 1999.

BENNETT, Tony. The exhibitionary complex. In: DIRKS, Nicholas; ELEY, Geoff; ORTNER, Sherry (Orgs.). Culture/Power/ History. A reader in contemporary social theory. New Jersey: Princeton University Press, 1994.

CASHMAN, Sean. America in the Gilded Age: from the death of Lincoln to the rise of Theodore Roosevelt. 3rd ed., New York: New York University Press, 1993.

\section{GANPHLAC}


CHARTIER, Roger. A história cultural: entre práticas e representações. Rio de Janeiro: Editora Bertrand, 1990.

CHENEY, Margaret; UTH, Robert. Tesla, Master of Lightning. New York: Barnes \& Noble Books, 1999.

CONDIT, Carl. The Chicago School of Architecture. A history of commercial and public building on the Chicago area, 1875-1925. Chicago: The University of Chicago Press, 1964.

EVERDELL, William. Os primeiros modernos. Rio de Janeiro: Editora Record, 2000.

GIMENES, Gabriela. Estados Unidos e América Latina nas páginas do Chicago Tribune: Pan-americanismo e Exposição Universal de Chicago (1889-1894). São Paulo: Departamento de História, FFLCH-USP, 2016 (mimeo).

HALES, Peter. Constructing the Fair: Platinum Photographs by C. D. Arnold of the World's Columbian Exposition. Chicago: Art Institute of Chicago, 1993.

HANDY, Moses. Official directory of the World's Columbian Exposition - A Reference Book. Chicago: Publishers to the World's Columbian Exposition, 1893.

HARDMAN, Francisco. Trem Fantasma: a ferrovia Madeira-Mamoré e a modernidade na selva. $2^{a}$ ed. São Paulo: Companhia das Letras, 2005.

HOFSTADTER, Richard. Turner and the Western Revolt. In: The progressive historians: Turner, Beard, Parrington. Nova York: Alfred A. Knopf, 1969.

JOHNSTON, Louis; WILLIAMSON, Samuel. Sources and Techniques Used in the Construction of Annual GDP, 1790-2014. Disponível em: http://www.measuringworth.com/usgdp/sourcegdp.php Acesso em: 20/12/2015.

JONNES, Jill. Empires of Light. Edison Tesla, Westinghouse and the race to electrify the world. New York: Random House, 2003.

JUNQUEIRA, Mary. Ao sul do Rio Grande. Imaginando a América Latina em Seleções: oeste wilderness e fronteira (1942-1838). Bragança: EDUSF, 2000.

KAPLAN, Amy. Left Alone with America: The Absence of Empire in the Study of American Culture. In: KAPLAN, Amy; PEASE, Donald (Orgs.). Cultures of United States Imperialism. 2nd ed. Durham/London: Duke University Press, 1995.

KOSSOY, Boris. Realidades e ficções na trama fotográfica. $4^{\mathrm{a}}$ edição. São Paulo: Ateliê Editorial, 2009.

\section{GANPHLAC}


MAUAD, Ana Maria. Através da imagem: fotografia e história interfaces. Revista Tempo, Rio de Janeiro, vol. 1, nº. 2, 1996.

Poses e Flagrantes: Ensaios sobre história e fotografias. Niteroi: Editora da UFF, 2008.

MILLER, Donald. City of the century: the epic of Chicago and the making of America. New York: Simon \& Schuster paperbacks, 2003.

MOTT, Frank. American Journalism. A history of newspapers in the United States through 250 years $(1640$ - 1940). New York: Macmillian, 1941.

MUCCIGROSSO, Robert. Celebrating the New World. Chicago's Columbian Exposition of 1893. Chicago: I.R. Dee, 1993.

O’GORMAN, Edmundo. A invenção da América: reflexão a respeito da estrutura histórica do Novo Mundo e do sentido do seu devir. São Paulo: Editora da UNESP, 2002.

PESAVENTO, Sandra. Exposições Universais: Espetáculos da modernidade no século XIX. São Paulo: Hucitec, 1997.

PRATT, Mary Louise. Os olhos do império: relatos de viagem e transculturação. São Paulo: EDUSC, 1999.

REICHLEY, James. The life of the parties: a history of American political parties. New York: The Free Press (Macmillan), 1992.

ROSENBERG, Chaim. America at the Fair: Chicago's 1893 World's Columbian Exposition. Chicago: Arcadia Publishing, 2008.

RYDELL, Robert. All the World's a Fair: Visions of Empire at American International Expositions, 1876-1916. Chicago: The University of Chicago Press, 1984.

The Culture of Imperial Abundance: World's Fairs in the Making of American Culture. In: BRONNER, Simon (Ed.). Consuming Visions: Accumulation and Display of Goods in America, 1880-1920. New York: Norton, 1989.

The Reason Why the Colored American Is Not in the World's Columbian Exposition: The Afro-American's Contribution to Columbian Literature. Chicago: University of Illinois Press, 1999.

SAID, Edward. Cultura e Imperialismo. Edição de bolso. São Paulo: Cia das Letras, 2011.

\section{GANPHLAC}

Revista Eletrônica da ANPHLAC, ISSN 1679-1061, №. 22, p. 147-181, Jan./Jun., 2017.

http://revista.anphlac.org.br 
SALVATORE, Ricardo. Imágenes de un imperio: Estados Unidos y las formas de representación de América Latina. Buenos Aires: Sudamericana, 2006.

SANDLER, Martin. Photography: An illustrated history. New York: Oxford University Press, 2002.

SCHLERETH, Thomas. Columbia, Columbus and Columbianism. The Journal of American History, v. 79, n. 3, 1992.

TRACHTENBERG, Alan. The incorporation of America: culture and society in the Gilded Age. New York: Hill and Wang, 1997.

TURNER, Frederick. The frontier in American history. $2^{\mathrm{a}}$ edition. Tucson: The University of Arizona Press, 1992. 